\title{
Does Financial Statement Comparability Facilitate SEC Oversight?
}

\begin{abstract}
This study examines the impact of cross-firm financial statement comparability on regulatory oversight of accounting quality. Consistent with the notion that comparable accounting systems enhance regulators' ability to identify accounting deviations from financial reporting, we find that the likelihood that the SEC issues a comment letter on $10-\mathrm{K}$ filings that have poor accounting quality increases with financial statement comparability. Further analysis reveals that the regulatory benefits from financial statement comparability are more salient when the SEC faces higher monitoring constraints in filing reviews. Overall, we provide novel evidence suggesting that higher financial statement comparability improves the efficacy of the SEC's oversight of accounting quality by reducing the information costs associated with cross-firm comparisons.
\end{abstract}

Keywords: SEC filing reviews, comment letters, financial statement comparability, accounting quality, cross-firm comparisons

JEL Codes: M41, M48 


\section{INTRODUCTION}

In its role in monitoring and enhancing firms' compliance with disclosure and accounting requirements, the Securities and Exchange Commission (SEC) reviews periodic corporate filings, following up with comment letters when issues or questions arise during the review (SEC 2019a). These filing reviews are completed by industry-level offices under the SEC's Division of Corporation Finance (DCF). This industry-level structure, combined with the SEC's acknowledged reliance on peer benchmarking in assessing accounting quality (Lewis 2012), suggests that cross-firm comparisons are an important part of the SEC's review process. We posit that comparable accounting systems facilitate the evaluation of accounting quality across firms and thus improve the efficacy of the SEC's filing review process. Specifically, this study investigates 1) whether the probability that the SEC issues a comment letter for poor accounting quality increases in financial statement comparability (i.e., the degree to which a firm's accounting system is comparable to that of its peers), and 2) the circumstances under which this relation is more pronounced.

We propose that high financial statement comparability among peer firms facilitates the SEC's identification of filing firms' deviations from accounting rules during its filing reviews. Higher financial statement comparability improves users' ability to identify differences and similarities across firms' financial statements and in turn allows for more meaningful cross-firm comparisons (e.g., De Franco, Kothari, and Verdi 2011 (DKV hereafter); Choi, Choi, Myers, and Ziebart 2019; Chen, Collins, Kravet, and Mergenthaler 2018). As such, to the extent that crossfirm comparisons are part of regulatory filing reviews, we conjecture that when a firm has higher financial statement comparability with its peer firms, the DCF employees are better able to identify deviations from financial reporting rules and are thus more likely to issue a comment letter on 
these filings of poor accounting quality.

To examine the effect of cross-firm comparable accounting systems on the SEC's assessment of accounting quality, we regress the issuance of an accounting-related comment letter on poor accounting quality and evaluate whether the association is strengthened by financial statement comparability. We follow DKV in measuring a firm's financial statement comparability with its peers (i.e., similar-sized firms from the same industry). Consistent with our prediction, the likelihood that the SEC detects accounting deviations suggestive of poor accounting quality (proxied by discretionary accruals) is significantly higher when a filing firm's financial statement comparability is high relative to when it is low. Without taking into account the cross-sectional variation in financial statement comparability, we find an insignificant association between a filing firm's accounting quality and comment letter issuance, further highlighting the important role of comparable accounting systems in the SEC's assessment of accounting quality.

Next, we evaluate how the SEC's monitoring constraints in the review process affect the extent to which financial statement comparability improves its detection of poor accounting quality. Prior studies demonstrate that monitoring constraints adversely impact the SEC's ability to oversee firms' financial reporting (e.g., Ege, Glenn, and Robinson 2020; Gunny and Hermis 2020). We conjecture that the reduced information costs that arise from the use of highly comparable peer benchmarks could help the SEC overcome the monitoring constraints it faces in filing reviews. Consistent with this prediction, the positive effect of financial statement comparability on the SEC's detection of poor accounting quality is more prominent when the SEC suffers from high monitoring constraints, as proxied by fewer SEC review staff and dissimilar filing formats. This result supports our assertion that the SEC's use of comparisons among peer firms with high financial statement comparability is a cost-efficient tool for assessing firms' 
accounting quality.

We perform several tests to help assess the extent to which our results can be attributed to economic rather than financial statement comparability. First, we repeat our main test by including a measure of cross-firm economic similarities (Chen et al. 2018) in the empirical analysis. This test result shows that while the effect of financial statement comparability on the SEC's review process remains significant, that of economic comparability is insignificant. Second, exploiting the SEC's 2007 elimination of the reconciliation requirement for cross-listed firms following International Financial Reporting Standards (IFRS), we employ the difference-in-differences methodology and find that the negative shock to financial statement comparability impedes the SEC's ability to assess accounting quality, consistent with our prediction. Third, using an inputbased comparability measure (Peterson, Schmardebeck, and Wilks 2015), which contrasts with DKV's output-based measure, we continue to find similar results. As such, while we cannot completely rule out the effects of economic comparability, the different pieces of evidence collectively suggest that our finding of a positive association between financial statement comparability and the SEC's detection of poor accounting quality is likely due to high cross-firm comparability in financial reporting.

Our study contributes to several strands of research. First, we add to the literature on regulatory oversight and the effectiveness of the SEC's comment letter process. Highlighting the information value of peers with higher financial statement comparability to the regulatory filing process, we find that comparable accounting numbers across firms enhance the SEC's ability to identify accounting deviations suggestive of poor accounting quality. In doing so, this study addresses the call for more research into ways to improve the efficacy of the SEC's filing review process (Cunningham and Leidner 2020). Prior studies examine whether the overall quality of SEC 
oversight is adversely affected by various external constraints such as geographic distance (Kedia and Rajgopal 2011), seasonally compressed periodic filings (Gunny and Hermis 2020), and an influx of IPO and acquisition transitional filings (Ege et al. 2020). Distinct from this line of prior research, we investigate the effect of a filing firm's relative attribute of financial reporting on the SEC's filing review process; finding that financial statement comparability enhances the SEC's evaluation of accounting quality. Thus, our study provides an explanation for the puzzling mixed evidence in prior research as to whether firms with poor accounting quality are more likely to receive comment letters (e.g., Cunningham, Johnson, Johnson, and Lisic 2020; Hribar, Kravet, and Wilson 2014).

Second, we contribute to the literature on the benefits of cross-firm comparable accounting systems. Prior studies reveal extensive evidence supporting the view that higher financial statement comparability enhances the evaluation of a firm's economic performance for various types of accounting information users, including financial analysts (DKV; Bradshaw, Miller, and Serafeim 2009; Peterson et al. 2015), debt market participants (Kim, Kraft, and Ryan 2013), equity investors (Choi et al. 2019), M\&A firms (Chen et al. 2018), and boards of directors (Lobo, Neel, and Rhodes 2018; Nam 2020). That said, the existing literature provides little evidence on the effect of financial statement comparability on the decision making of another heavy user of accounting information, i.e., the SEC. Our study documents the benefit of higher financial statement comparability for regulators when inspecting the adequacy of a firm's financial reporting. We provide novel evidence suggesting that comparable accounting systems aid the SEC's evaluation of firms' filings.

Finally, this study has timely implications for the SEC given the 2019 realignment of its disclosure review program, which, among other changes, included a reduction in the number of 
filing review industry-level (AD) offices from eleven to seven. ${ }^{1}$ The SEC's suggested change in its organizational structure aims to make its filing reviews more efficient. Thus, our finding that cross-firm comparable financial reporting lowers the information costs associated with filing reviews and attenuates the negative effects of SEC monitoring constraints would be of particular interest to the SEC in its continuing efforts to reduce regulatory filing review costs.

The rest of this paper proceeds as follows. Section 2 presents the background and related literature review and develops our hypothesis. Section 3 describes our sample and variable measurement. We present and discuss our empirical results in sections 4 and 5. Section 6 concludes.

\section{LITERATURE REVIEW AND HYPOTHESIS DEVELOPMENT}

\subsection{SEC Filing Review}

One of the SEC's key functions is to oversee the disclosure of firms' financial information to the public. A critical component of this oversight is the SEC's review of firms' periodic reporting (SEC 2019b), which has the goal of monitoring firms' compliance and improving the quality of their disclosure. Under Section 408 of the Sarbanes-Oxley Act of 2002 (SOX), the SEC is required to review firms' periodic filings at least once every three years. Cunningham and Leidner (2020) document, however, that the SEC does so more often, reviewing nearly half of the firms in any given year. The DCF selectively reviews filings based on specific criteria identified in SOX as well as any other criteria the SEC determines to be important. ${ }^{2}$ The SEC focuses on

\footnotetext{
${ }^{1}$ See https://www.sec.gov/corpfin/announcement/cf-disclosure-program-realignment.

${ }^{2}$ Section 408 of SOX specifies that "the Commission shall consider, among other factors- (1) issuers that have issued material restatements of financial results; (2) issuers that experience significant volatility in their stock price as compared to other issuers; (3) issuers with the largest market capitalization; (4) emerging companies with disparities in price to earnings ratios; (5) issuers whose operations significantly affect any material sector of the economy; and (6) any other factors that the Commission may consider relevant." In addition to selecting which firm to review, the DCF can also vary the extent of the review (e.g., a full "cover to cover" review, financial statements and related
} 
items that appear to violate accounting rules or that are materially deficient in clarity (SEC 2019a). When the commission believes that the firms' compliance can be enhanced, it issues a comment letters to the firm. ${ }^{3}$ Within 10 business days of the receipt of this initial comment letter, the firm is required to respond to the comments and questions the regulator posed. The comment letter process can span multiple rounds and ends with a closing letter indicating that the SEC is satisfied that all comments have been addressed.

The SEC's focus on potential accounting violations and material deficiencies in their reviews suggests that one objective of the filing review process is to detect poor quality accounting. However, the extant literature offers only mixed empirical evidence of a relation between comment letter issuance and accounting quality. Consistent with the SEC issuing more comment letters to firms with lower accounting quality, Hribar et al. (2014) find a positive association between comment letter issuance and unexplained audit fees. Meanwhile, the association between SEC comment letter issuance and other conventional empirical proxies of accounting quality, such as accruals-based and real earnings management, is insignificant (Cunningham et al. 2020). Moreover, in stark contrast to the view that the SEC detects poor quality accounting, Hribar et al. (2014) document that the likelihood of that the commission issues a comment letter increases in financial reporting quality, as proxied by accruals quality (Dechow and Dichev 2002).

The SEC has limited oversight resources while being responsible for overseeing a large number of firms' filings. ${ }^{4}$ Thus, prior studies often question whether resource limitations constrain

disclosure, or a targeted review). Prior studies generally confirm that the Section 408 criteria (e.g., stock price volatility, market capitalization) impact comment letter issuance (e.g., Cassell, Dreher, and Myers 2013; Heese, Khan, and Ramanna 2017; Johnson and Petacchi 2017).

${ }^{3}$ The review may not result in a comment letter if the SEC has no questions or concerns that require further clarification.

${ }^{4}$ From 2004-2016 the SEC received a total of 8,726,958 filings (average of 671,304 filings per year), and the DCF employed an average of 364 industry-level employees a year (assigned an industry AD code). Thus, each industrylevel review employee was responsible for approximately $1,844(671,304 / 364)$ filings per year. Filing data was 
its ability to oversee firms' financial reporting (e.g., Ege et al. 2020; Blackburne 2014; Gunny and Hermis 2020). With respect to the monitoring constraints, Kedia and Rajgopal (2011) and Files (2012) show that the SEC is more likely to investigate a firm whose review costs are lower (i.e., the firm's location is closer to the SEC office and the upfront enforcement costs are lower, respectively).

\subsection{Financial Statement Comparability}

The Financial Accounting Standards Board (FASB) (2010) states that information about a reporting entity is more useful when it can be compared with similar information about other entities, highlighting the important role of cross-firm comparisons in evaluating accounting information. Financial statement comparability is a relative or comparative concept, not an absolute or independent criterion like other accounting characteristics (Sohn 2016). In the conceptual framework for financial reporting, the FASB (2010) defines comparability as a qualitative characteristic of financial information that enhances users' ability to identify and understand similarities and differences between items. That is, when evaluating a firm's financial statements, the availability of comparable benchmark peer firms' financial statements (i.e., more comparable financial reporting) lowers the information acquisition and processing costs and increases the overall quantity and quality of information about the firm.

Prior academic studies extensively document the benefits from more comparable financial reporting. Using an output-based comparability measure based on the earnings-return relation, DKV find that higher financial statement comparability improves financial analysts' forecasts. Prior findings also show that cross-firm comparable accounting systems enhance accounting

obtained from https://www.sec.gov/derADatADera_edgarfilingcounts. The number of DCF employees per AD Office was obtained from a Freedom of Information Act (FOIA) request. 
information users' decision making in various ways, including reducing investors' information asymmetry (Chen, Miao, and Shelvin 2015), increasing the profitability of managers' acquisition decisions (Chen et al. 2018), reducing debt market participants' uncertainty (Kim et al. 2013), improving the informativeness of stock prices and earnings (respectively, Choi et al. 2019 and Fang, Iselin, and Zhang 2017), and improving compensation contract efficiency (Lobo et al. 2018; Nam 2020). Moreover, financial statement comparability captures similarities in accounting choices and estimates across firms, which in turn predicts future restatements (Campbell and Yeung 2017).

High financial statement comparability not only facilitates the evaluation of accounting information through cross-firm comparisons, it also disciplines firms' accounting and disclosure choices. Barth, Landsman, and Lang (2008) show that the increase in financial statement comparability due to IFRS adoption leads to less earnings management and more timely loss

recognition. Using DKV's comparability measure in a U.S. Generally Accepted Accounting Principles (GAAP) setting, other studies find that highly comparable financial information disciplines managers from withholding bad news ( $\mathrm{Kim}, \mathrm{Li}, \mathrm{Lu}$, and $\mathrm{Yu}$ 2016) and improves audit efficiency and accuracy (Zhang 2018). Moreover, Sohn (2016) documents that when a firm has peer firms with high financial statement comparability, it engages in less accruals-based, but more real earnings management. Yet in the existing literature, little is known about a regulatory channel through which financial statement comparability impacts the oversight of accounting quality.

\subsection{Hypothesis Development}

The SEC has long been concerned about poor accounting quality in the form of earnings management, which erodes the ability of accounting information to reflect a company's true 
financial performance (Levitt 1998). Underscoring the importance of this concern, SEC enforcement efforts have scrutinized firms for even the least aggressive measures taken to meet earnings targets. ${ }^{5}$ Moreover, the Division of Economic and Risk Analysis has developed analytical tools that identify "discretionary accounting choices" and "earnings management" practices (Lewis 2012), highlighting the SEC's continuous efforts to detect deviations from financial reporting rules, which is a primary focal point of its regulatory oversight of filings.

A filing firm's accounting deviation often manifests itself through cross-firm comparisons (e.g., Lee, Ma, and Wang 2015; Ramnath 2002). The SEC acknowledges its reliance on cross-firm comparisons as part of efforts to detect earnings management, and it implemented the Accounting Quality Model (AQM), a regulatory tool designed to evaluate a firm's financial disclosures. Specifically, AQM takes filing information across firms to identify discretionary accruals that are indicative of aggressive earnings management, thereby facilitating the SEC's assessment of accounting quality. If a filing firm is found to have suspicious accounting patterns, relative to its peer group, then the SEC could issue a comment letter calling for additional scrutiny. ${ }^{6}$

Facing a heavy workload and aiming to send comment letters within 30 days of a firm's filing (SEC 2019b), the SEC could benefit from comparing cross-firm accounting numbers as a low-cost and efficient means of reviewing filings, rather than evaluating a firm's 10-K report in isolation. In fact, the organizational structure of the DCF's industry-level AD Offices is designed to facilitate firm-to-firm financial statement comparisons, which enables its staff to specialize in industry-specific accounting practices (Grove, Johnsen, and Lung 2016).

\footnotetext{
${ }^{5}$ See https://corpgov.law.harvard.edu/2019/12/17/sec-cracks-down-on-earnings-management/ and https://news.bloomberglaw.com/securities-law/insight-sec-is-watching-earnings-management-disclosures regarding the SEC's recent emphasis on deterring earnings management.

${ }^{6}$ See https://www.sec.gov/news/speech/2012-spch121312cmlhtm.
} 
Given the considerable usage of cross-firm comparisons in the review process, the extent to which a firm's accounting system is comparable to those of its peers should impact the SEC's detection of earnings management in financial filings. We posit that the SEC's ex-ante knowledge about financial statement comparability, gleaned from cumulative filing reviews over time, directly affects its selection and interpretation of informative peer benchmarks, which is essential to conducting meaningful cross-firm comparisons. Specifically, more comparable accounting systems make it easier for the SEC to distinguish similarities and differences between a firm's accounting and that of its peers. For firms with high financial statement comparability, as observed from previous filings, the DCF employees are better equipped to use cross-firm comparisons to identify accounting deviations suggestive of poor accounting quality. On the other hand, in the absence of meaningful benchmark peer firms (i.e., low financial statement comparability) the time and effort needed to reviewing filings increases, impeding the SEC's detection of poor accounting quality. This reasoning leads to our hypothesis (in alternative form) as follows:

HYPOTHESIS. The likelihood that an SEC comment letter is issued to a firm with deviations from financial reporting rules is greater when the firm's accounting system is more comparable to that of its peers relative to when it is less comparable.

By focusing on a relative attribute of a firm, specifically its financial reporting comparability, the above hypothesis is distinct from prior studies which mainly focus on firm-specific absolute characteristics (e.g., size, profitability) as determinants of the SEC's comment letter issuance (e.g., Cassell et al. 2013; Cunningham and Leidner 2020).

\section{DATA AND SAMPLE CHARACTERISTICS}

\subsection{Sample Selection}

Table 1, panel A outlines our sample construction process. We collect comment letters that 
the SEC issued on 10-K filings from fiscal years 2004 to 2016 . We focus on $10-\mathrm{K}$ filings rather than other periodic filings (e.g., 10-Qs) because the SEC usually begins its review with them (US Senate 2002), which suggests that $10-\mathrm{K}$ filings are the SEC's primary periodic filing of interest. ${ }^{7}$

We construct our main dependent variable, $C L \_A c c t$, as a dummy variable equal to one if a firm receives an accounting-related comment letter on its $10-\mathrm{K}$ filing for the fiscal year $\mathrm{t}$, and zero otherwise. Since not all comment letters include accounting topics, we focus on those that do to better capture the effect of financial statement comparability on the SEC's ability to identify accounting, as opposed to non-accounting, issues (e.g., M\&A or risk disclosures). We further identify comment letters related to core earnings topics (e.g., revenue, cost of goods sold), CL_Core, not only because such topics are directly subject to earnings management that is the SEC's particular concern, but also because DKV's approach uses earnings to capture a firm's overall accounting outcome. ${ }^{8}$ We obtain data from Compustat, CRSP, and Audit Analytics to construct variables of financial reporting quality and economic fundamentals. The final sample consists of 24,075 firm-year observations from fiscal years 2004 through 2016. Panel B illustrates the distribution of firm-year observations in our sample at the AD Office level. ${ }^{9}$

\subsection{Measuring Financial Statement Comparability}

We follow DKV in measuring financial statement comparability between two firms. Their methodology captures how closely the same economic events (as reflected by stock returns) that

\footnotetext{
${ }^{7}$ We use LIST_FORM_DATES from the Comment Letter and Comment Letter Conversations databases in Audit Analytics to classify a comment letter as relating to a 10-K filing when the form reviewed includes "10-K", "10-KT", "10K405", or "10KSB". We use the 10-K filing date referenced in the comment letter to match it to the fiscal year that it concerns. We also determine the comment letters' accounting topics based on Audit Analytics' classification of "Accounting Rule and Accounting Disclosure Type Issues." Our initial sample period begins in 2004 because the SEC did not release comment letters on filings made before August 1, 2004.

${ }^{8}$ We follow Cassell et al. (2013) and Palmrose and Scholtz (2004) in identifying topics related to core earnings.

${ }^{9}$ We match a firm's SIC code to the DCF's SIC Code List, which shows the DCF's allocation of SIC codes to the AD offices. The code list was found on https://www.sec.gov/info/edgar/siccodes.htm, as of 11/5/2015.
} 
impact two firms are mapped into their accounting earnings. For each firm-year observation of Earnings and Return, we first estimate the following equation using data from the previous 16 quarters (12 quarters minimum):

$$
\text { Earningsit }=\alpha_{i}+\beta_{i} \text { Return }_{i t}+\varepsilon_{i t}
$$

Earnings equals quarterly income before extraordinary items scaled by lagged total assets and Return equals the contemporaneous quarterly stock return. The coefficient estimates from equation (1), $\hat{\alpha}_{i}$ and $\hat{\beta}_{i}$, are firm-specific accounting system parameters that map economic events into reported earnings numbers for firm $i$. Similarly, we estimate $\hat{\alpha}_{j}$ and $\hat{\beta}_{j}$ as the parameters of the accounting system of peer firm $j$. Next, we calculate firm $i$ 's predicted earnings by applying the parameter estimates of the accounting systems of firms $i$ and $j$, respectively, to firm $i$ 's stock returns as follows:

$$
\begin{aligned}
& \mathrm{E}(\text { Earnings })_{i i t}=\hat{\alpha}_{i}+\hat{\beta}_{i} \text { Return }_{\mathrm{it}} ; \\
& \mathrm{E}\left(\text { Earnings }_{i j t}=\hat{\alpha}_{j}+\hat{\beta}_{j} \text { Return }_{\mathrm{it} .} .\right.
\end{aligned}
$$

Equation (2) estimates firm i's predicted earnings based on the firm's accounting system parameters, whereas equation (3) estimates the predicted earnings of firm $i$ based on the accounting system parameters of firm $j$. Financial statement comparability between firms $i$ and $j, F S C_{i j}$, is defined as the absolute difference between the expected earnings estimated from equations (2) and (3), averaged over the preceding 16 quarters (and multiplied by -1 so that our measure is increasing in comparability):

$$
F S C_{i j t}=(-1) \times(1 / 16) \times \sum_{t-15}^{t} \mid \mathrm{E}(\text { Earnings })_{i i t}-\mathrm{E}(\text { Earnings })_{i j t} \mid .
$$

Since $F S C_{i j t}$ is a pairwise measure of the extent to which two firms have similar earningsreturns relations, it is aggregated at the level of firm $i$ and year $t$ to facilitate our empirical analysis. As for peer firm $j$, because the SEC does not disclose the peer firms it uses in the review process, 
we must make assumptions in identifying the peers likely to be relevant and useful to the SEC in reviewing firm $i$ 's filing. Our first peer selection criterion is industry membership. The DCF's industry-level organizational structure suggests that peer comparisons made during the filing review process are likely to take place within an industry. Moreover, firms' financial reporting processes are subject to various industry-specific factors (e.g., regulations, competition, industry experts), and financial reporting outputs are systematically correlated within industry (Dechow and Dichev 2002). ${ }^{10}$

In addition, we take into account firm size when selecting peers from the same industry. Firm size is found to be associated with managers' choice of accounting methods (Hagerman and Zmijewski 1979). Moreover, firms of different sizes are exposed to different shocks and face different constraints in responding to external shocks (Albuquerque 2009). That is, firms of similar size are likely to face similar accounting issues, which makes them more informative benchmarks in cross-firm comparisons. ${ }^{11}$ We thus conjecture that when assessing a firm's accounting quality, the SEC is likely to find it useful to benchmark a firm's financial statements to those of firms that are both in the same industry and of similar size. In line with this reasoning, we measure Comparability $_{i t}$ as the average of $F S C_{i j t}$ calculated using the ten most similar-sized (total assets) peer firms from the same industry (two-digit SIC). ${ }^{12}$

\footnotetext{
${ }^{10}$ For example, accounting policy choices in the oil and gas industry are particularly susceptible to costly political actions linked to firm performance (e.g., Watts and Zimmerman, 1990).

${ }^{11}$ The ideal peer group should include firms that are similar along various fundamental characteristics (e.g., size, growth opportunity, leverage). However, considering too many characteristics in peer selection is not practical because it could result in too few firms. Albuquerque (2009) shows that size is a peer selection criterion that effectively subsumes the information in many of these fundamental characteristics.

${ }^{12}$ In untabulated tests, we repeat our empirical analysis with various alternative peer groups. Our main result is robust to choosing 1) all firms in the same industry as the firm of interest, and 2) four or ten industry peers that produce the highest $F S C$ scores relative to the firm of interest. Furthermore, we conduct a falsification test by choosing the 10 least similarly sized, as opposed to the most similarly sized, industry peer firms. We find that our empirical finding becomes insignificant. This result validates our choice of firm size as a meaningful peer selection criterion that aids in the identification of the peer firms that the SEC is likely to use in the review process.
} 


\subsection{Measuring Poor Accounting Quality}

A greater magnitude of discretionary accruals can indicate higher earnings management, which represents lower accounting quality (e.g., Dechow, Ge, and Schrand 2010). To capture material accounting deviations about which the SEC is primarily concerned in the review process, we measure discretionary accruals, Disc_Accr, as the absolute value of the firm-specific residuals estimated using the following modified cross-sectional Jones model (Jones 1991; Kothari, Leone, and Wasley 2005) for each two-digit SIC-year grouping:

$$
T A_{i t}=\gamma_{1}+\gamma_{2}\left(\Delta R E V_{i t}-\Delta A R_{i t}\right)+\gamma_{3}\left(P P E_{i t}\right)+\varepsilon_{i t},
$$

where $T A$ is total accruals, $\triangle R E V$ is the change in revenues, $\triangle A R$ is the change in accounts receivables, and $P P E$ is property, plant, and equipment. We scale the variables (including the intercept) by the lagged total assets.

\subsection{Summary Statistics}

Table 2 shows the summary statistics. In panel A, we find that $27 \%$ (16\%) of our sample firm-years received an accounting-related (core earnings-related) comment letter about their 10-K filing, $C L \_A c c t$ (CL_Core). Further, over half of the firms (58\%) that did not receive a comment letter on its $10-\mathrm{K}$ filings for the previous two years, $\mathrm{t}-1$ and $\mathrm{t}-2$, did so for the $10-\mathrm{K}$ filing for year $\mathrm{t}\left(\mathrm{CL} \_3 \mathrm{Yr}\right) \cdot{ }^{13}$ The mean (median) value of Comparability, measured as the average $F S C$ between

\footnotetext{
${ }^{13}$ Reflecting the SEC's minimum requirement of a review every three years, $C L \_3 Y r$ is equal to 1 if the firm received a comment letter about its $10-\mathrm{K}$ filing for the fiscal years ending in $\mathrm{t}$, and 0 if the firm did not receive such a letter in years t, t-1 and t-2. Thus, by construction, $C L \_3 Y r$ holds constant the probability of being reviewed at least once, which mitigates the concern that researchers cannot ascertain whether a filing was reviewed but no comment letter issued (Cunningham and Leidner 2020). The construction of $C L \_3 Y r$ requires that firm-years that received a $10-\mathrm{K}$ related comment letter in the past two years be removed. Given that the SEC reviews nearly half of firms in any given year, which is more often than required (Cunningham and Leidner, 2020), $C L \_3 Y r$ could exclude firms that are very likely to be subject to a review in the focal year. Thus, we primarily focus on $C L \_A c c t$ and $C L \_C o r e$ as our main dependent variables to allow our results to be more generalizable to a larger set of firms.
} 
a firm and its ten industry-size peer firms, is $-0.036(-0.022) .{ }^{14}$

Panel B reports that relative to firms receiving no accounting-related comment letter $\left(C L \_A c c t=0\right)$, those that receive such a letter about their $10-\mathrm{K}$ filings $\left(C L \_A c c t=1\right)$ are larger ((Log(Mkt Cap)), older (Firm Age), less likely to report a loss (Loss), and more comparable to peer firms in financial reporting (Comparability). In panel C, we further find that firms with high financial statement comparability $($ High_Comp=1) are more likely to receive comment letters compared to those with low financial statement comparability $\left(H i g h \_C o m p=0\right)$, suggesting that the SEC may more easily identify questions or comments in more comparable firms' filings. Table 3 presents the correlations across our main variables of interest and the control variables.

\section{MAIN EMPIRICAL ANALYSIS}

\subsection{Baseline Study: SEC Comment Letter Issuance and Accounting Quality}

Before testing our main hypothesis, we investigate the impact of a firm's accounting quality on the likelihood that the firm receives an SEC comment letter using the following logit regression:

$$
\operatorname{Pr}\left(\text { Comment Letter }_{i t}=1\right)=\theta_{0}+\theta_{1} \text { Disc_Accr }_{i t}+\Sigma \text { Controls }+\varepsilon_{i t},
$$

where the dependent variable is one of $C L \_A c c t, C L \_C o r e$, or $C L \_3 y r$. Disc_Accr is the absolute value of discretionary accruals measured based on the modified Jones model (Jones 1991; Kothari et al. 2005). Following prior research (e.g., Johnston and Petacchi 2017; Cassell et al. 2013; Zhang 2018), we control for other factors that impact the likelihood of receiving a comment letter;

\footnotetext{
${ }^{14}$ Our financial statement comparability measure (years 2004-2016) is slightly more negative (i.e., less comparable) than the mean and median of 0.025 (-0.015) for the years 1981-2008, reported in DKV. This is consistent with the data (up to 2013) disclosed on Professor Rodrigo Verdi's website, which reveals that DKV's comparability measure has become more negative in recent years.
} 
volatility, firm size, firm age, net loss, bankruptcy risk, mergers and acquisitions, external financing, big 4 auditors, $2^{\text {nd }}$ tier auditors, special items, and restatement announcements. Following Chen et al. (2018), we also include stock return correlation with industry peers and stock return synchronicity to control for economic similarities across firms. Year dummies and AD Office dummies are included and standard errors are clustered at the firm level. If the SEC is more likely to issue comment letters to firms with poor accounting quality, we expect to observe $\hat{\theta}_{1}>0$.

Without considering the impact of financial statement comparability (Table 4), we find no evidence supporting that poor accounting quality, as proxied by Disc_Accr, is positively associated with the SEC's issuance of a comment letter, consistent with Cunningham et al. (2020). Considering the SEC's substantial concerns about earnings management (e.g., Levitt 1998), it is puzzling to observe an insignificant empirical association between comment letter issuance and the magnitude of abnormal accruals. To the extent that the SEC's assessments of accounting quality substantially rely on cross-firm comparisons, disregarding financial statement comparability in estimating equation (6) would reduce a researcher's empirical power to capture the SEC's ability to detect accounting deviations in the review process.

\subsection{Financial Statement Comparability and the SEC's Evaluation of Accounting Quality}

In this section, we test our hypothesis by examining how the association between the SEC's comment letter issuance and accounting quality varies depending on a filing firm's financial statement comparability, as observed by the SEC from previous filings. Specifically, we estimate equation (7), which includes Disc_Accr interacted with High_Comp, as follows:

$$
\operatorname{Pr}(\text { Comment Letter } i t=1)=\varphi_{0}+\varphi_{1} \text { Disc_Accr }{ }_{i t} \times H i g h \_C o m p_{i t-1}+\varphi_{2} \text { Disc_Accr }{ }_{i t}
$$




$$
+\varphi_{3} H i g h \_C o m p p_{i t-1}+\Sigma \text { Controls }+\varepsilon_{i t},
$$

where High_Comp is equal to one if Comparability, as measured at the end of the previous year, is above the annual median, and zero otherwise. ${ }^{15}$ The coefficient estimate on the variable of main interest $\left(\varphi_{1}\right)$ captures the difference in the likelihood that the SEC issues a comment letter that concerns a firm's poor accounting quality between firms of high and low financial statement comparability. ${ }^{16}$ That is, if the SEC is more capable of detecting poor accounting quality, as inferred through its comment letter issuances, when the firm's previous accounting numbers exhibit higher financial statement comparability, we expect to observe $\hat{\varphi}_{1}>0 .{ }^{17}$ Table 6 provides empirical support for our hypothesis, as evidenced by $\hat{\varphi}_{1}$ being positive and significant in every column. $^{18}$

The economic significance of the effect of financial statement comparability on the SEC's identification of poor accounting quality is meaningful. At the bottom of Table 5, the mean interaction effect of Disc_Accr $\times$ High_Comp, calculated by the procedure in Norton, Wang, and Ai (2004), is 0.153 for $C L \_A c c t, 0.132$ for $C L \_C o r e$, and 0.369 for $C L \_3 Y r$ at significant levels. The magnitude of these mean interaction effects is non-trivial relative to the unconditional mean

\footnotetext{
${ }^{15}$ We measure High_Comp at the end of the previous year to avoid a possible spurious correlation between Disc_Accr and High_Comp due to an overlap in the estimation periods. This measurement thus addresses a potential concern that a firm's financial reporting choice could simultaneously affect its accounting quality and its financial statement comparability. We continue to find similar results when measuring High_Comp in the current year (untabulated).

${ }^{16}$ High_Comp represents the extent to which a firm is comparable to its peers in accounting systems (as measured across firms as well as across time), which contrasts with a firm $i$ 's accounting quality for the specific year (as proxied by Disc_Accr) that is the SEC's primary focus in 10-K filing reviews. As such, financial statement comparability and discretionary accruals capture different aspects of a firm's financial reporting, which collectively helps SEC oversight. ${ }^{17}$ Zhang (2018) documents that financial statement comparability is positively associated with auditor performance. If accounting deviations are remedied by auditors that benefit from comparable accounting numbers prior to the SEC's review process, then our model could fail to find empirical support for our hypothesis. To further investigate this audit channel, when estimating equation (7), we include additional control variables for audit fees explained (unexplained) by cross-firm comparability in accounting systems, proxied by the fitted (residual) values from regressing audit fees on financial statement comparability. Our inferences remain unchanged (untabulated).

${ }^{18}$ Our inferences remain the same with 1) a subsample analysis without interaction terms, 2) a linear probability model estimation, 3) additional controls for product market competition and cross-firm overlap in institutional ownership, and 4) industry-adjusted control variables (all untabulated).
} 
of CL_Acct (0.273), CL_Core (0.158), and CL_3Yr (0.518). Moving from low to high comparability, these marginal effects suggest that a one standard deviation increase in Disc_Accr (i.e., a decline in accounting quality) increases the comment letter likelihood by approximately $1.4 \%(0.092 \times 0.153), 1.2 \%(0.092 \times 0.132)$, and $3.6 \%(0.092 \times 0.369)$ (in respective relation to CL_Acct, $C L \_C o r e$, and $\left.C L \_3 Y r\right) .{ }^{19}$ Overall, the results in Table 5 provide novel empirical evidence that the SEC's detection of poor accounting quality varies substantially with how comparable a filing firm's financial statements are to its peers, which further supports the critical role of cross-firm comparisons in regulatory filing reviews. ${ }^{20}$

\section{ADDITIONAL EMPIRICAL ANALYSIS}

\subsection{The Effect of Monitoring Constraints on the SEC's Filing Review}

To highlight the informational advantage of cross-firm comparisons in regulatory filing reviews, we explore how the SEC's monitoring constraints, captured by 1) resource limitations (section 5.1.1) and 2) the use of dissimilar filing formats (section 5.1.2), affect the role of financial statement comparability in improving the SEC's assessment of accounting quality. Prior studies show that the SEC's oversight over financial reporting is less effective when it is constrained (e.g., Gunny and Hermis 2020; Ege et al. 2020; Blackburne 2014). Furthermore, Kedia and Rajgopal (2011) suggest that when constrained, the SEC is more likely to focus on monitoring firms that are

\footnotetext{
${ }^{19} \mathrm{We}$ also calculate how the likelihood of receiving an accounting comment letter changes for high and low comparability firms with poor accounting quality (defined as the $90^{\text {th }}$ percentile of Disc_Accr). We then compare that likelihood to the likelihood that firms with strong accounting quality (defined as the $10^{\text {th }}$ percentile of Disc_Accr) will receive such a letter. We find that the former is $2.3 \%$ more likely to receive an accounting comment letter when its financial statement comparability is high relative to when it is low. On the other hand, the effect of comparability is limited when accounting quality is strong, (resulting in a $0.2 \%$ lower likelihood of receiving an accounting comment letter). These findings highlight that comparability primarily facilitates the discovery of issues at poor accounting quality firms (untabulated).

${ }^{20}$ Appendix 2 furthers our main empirical analysis using alternative proxies of financial reporting quality, including alternative models of accruals management, earnings volatility, accruals quality, and unexpected audit fees. We continue to find empirical evidence consistent with our hypothesis.
} 
less costly to investigate. To the extent that benchmarking a firm to its peers is a low cost way to evaluate a filing relative to a full evaluation of a firm in isolation, the SEC's reliance on cross-firm comparisons is likely to increase when it faces higher monitoring constraints. Likewise, the presence of highly comparable peer firms, which improves the informativeness from cross-firm comparisons of accounting numbers, will be especially valuable when the SEC seeks to overcome higher information-processing costs resulting from more severe monitoring constraints.

\subsubsection{SEC Staffing}

Because filing reviews are completed by DCF staff from industry-level AD Offices, inadequate staffing at a particular industry-office would likely constrain that office's ability to review filings thoroughly. To capture the monitoring resource constraints at the industry (AD Office) and year levels, we measure SEC Resources based on the annual number of DCF staff allocated to each industry-level AD Office. We re-estimate model (7) in the subsamples partitioned by the median of SEC Resources. To the extent that the SEC relies heavily on cross-firm comparisons when it experiences a shortage of monitoring resources, we expect the role of financial statement comparability in detecting poor accounting quality, as estimated by Disc_Accr $\times$ High_Comp, to be salient for the low SEC Resources subsample.

In panel A of Table 6, we measure SEC Resources using SEC staffing from year $\mathrm{t}+1$ because that is when the SEC is likely to conduct reviews of year $\mathrm{t} 10-\mathrm{K}$ filings. Consistent with our prediction, when SEC Resources are low (columns 1-3), the coefficient estimate on Disc_Accr $\times$ High_Comp is positive and significant ( $p$-values $<0.01)$. On the other hand, for high SEC Resources (columns 4-6), the corresponding coefficient estimate on the interaction is insignificant for $C L \_A c c t$ and $C L \_C o r e$, although it is positive (one-tailed 10\% significance) for 
$C L \_3 Y r .{ }^{21}$ In terms of magnitude, the mean interaction effects, shown at the bottom of Table 6 , panel A, in the low SEC Resources subsample are nearly twice as high as in our pooled sample from Table 5. ${ }^{22}$ Acknowledging that SEC staffing in year $\mathrm{t}+1$ could reflect expectations about accounting quality in year $\mathrm{t}$, we also measure SEC Resources as of year $\mathrm{t}$ and find similar results (panel B).

Overall, Table 6 provides empirical findings consistent with the view that the SEC's monitoring resource constraints are positively associated with its reliance on cross-firm comparisons with high comparability peer firms during the filing review process. Moreover, this result suggests that comparable accounting systems across firms could help attenuate the negative oversight consequences arising from limited monitoring resources (e.g., Ege et al. 2020).

\subsubsection{Filing Formats: XBRL}

Next, we examine the effect of monitoring constraints on the regulatory filing reviews caused by different filing formats, which derive from variations in the adoption of the eXtensible Business Reporting Language (XBRL). XBRL is an Internet-based data formatting standard that requires financial reporting items to be tagged within taxonomies, which contain definitions explaining what each reporting item captures and how it is represented in U.S. GAAP. As such, accounting information users benefit from the enhanced ability of interactive filings to incorporate machine-readable data into their decision models (SEC 2009). The SEC mandated the adoption of XBRL for 10-K filings on a phased basis from 2009 to 2011.

\footnotetext{
${ }^{21}$ Similar to Heitzman, Wasley, and Zimmerman (2010), we test the difference in the interaction term coefficient estimates across the two subsamples. The p-value (two-tailed) testing for the equality is $0.07,0.05$, and 0.15 for CL_Acct (column 1 vs. 4), CL_Core (column 2 vs. 5), and CL_3Yr (column 3 vs. 6), respectively (untabulated).

${ }^{22}$ When SEC Resources are low, a one standard deviation increase in Disc_Accr (i.e., a decline in accounting quality) increases the likelihood of $C L \_A c c t, C L \_C o r e$, and $C L \_3 Y r$ by approximately $2.9 \%(0.098 \times 0.293), 2.7 \%(0.098 \times$ $0.293)$, and $5.6 \%$ (0.098 x 0.571) respectively, where the standard deviation of Disc_Accr for the subsample of low SEC Resources is 0.098 (untabulated). This compares to $1.4 \%, 1.2 \%$, and $3.6 \%$ in the pooled sample from Table 5.
} 
A firm's use of XBRL makes it more efficient to reference its filing with peer firms' XBRL filings, saving the SEC time and effort in the review process. In other words, the SEC's information processing costs are likely to be greater when reviewing non-XBRL filings compared to XBRL filings. To the extent that comparable accounting systems help reduce the information costs arising from the heavy workload inherent to filing reviews, the SEC's reliance on informative benchmarks (i.e., peer firms with high financial statement comparability) in evaluating accounting quality is more pronounced when reviewing non-XBRL filings rather than XBRL filings. By repeating our main analysis in the subsamples of XBRL and non-XBRL filers separately (Table 7), we find empirical evidence consistent with this conjecture. ${ }^{23}$ The coefficient estimate on Disc_Accr $\times$ High_Comp is positive and significant in the subsample of 10-K filings with no XBRL tagging (columns 1 and 3) while it is positive but insignificant in the subsample of those with XBRL tagging (columns 2 and 4). ${ }^{24}$ That is, the regulatory benefits from high financial statement comparability is more pronounced for $10-\mathrm{K}$ filings in the non-XBRL format that requires higher information costs in the review process. Collectively, our empirical results highlight the information channel through which cross-firm comparisons with informative peers helps the SEC to identify filing firms' accounting deviations.

\subsection{Economic Comparability vs. Financial Statement Comparability}

\subsubsection{Economic Comparability Measure}

Given that financial reporting captures a firm's underlying economics, it is reasonable to

\footnotetext{
${ }^{23}$ We thank the authors of Bhattacharya, Cho, and Kim (2018) for providing us with their hand-collected data identifying firms that file XBRL-tagged 10-K reports vs. those that use the traditional HTML format.

${ }^{24}$ Table 7 does not include $C L \_3 Y r$ as a dependent variable because this measure requires three years of data and a firm may not be an XBRL (or non-XBRL) filer for all three years. Thus, by excluding $C L \_3 Y r$ we ensure that each subsample clearly captures either XBRL or non-XBRL filers.
} 
expect that economically comparable firms would also have comparable accounting numbers. DKV show that firms with similar economic characteristics (e.g., industry, size, growth) exhibit higher financial statement comparability. To the extent that in filing reviews, the SEC benefits from comparisons of economic fundamentals between firms rather than their accounting systems, one could argue that our results based on DKV's measure may be influenced by economic comparability. Thus, this section evaluates the extent to which our main results can be attributed to accounting, as opposed to economic, comparability among peer firms.

Following Chen et al. (2018), we estimate economic comparability by replacing the earnings variable in DKV's base model (equation 1) with operating cash flows. High_Econ_Comp is equal to one if a firm's average economic comparability relative to its similar-sized industry peer firms is above the median, and zero otherwise. Consistent with the notion that economically comparable peer firms could serve as valuable benchmarks in the SEC's review process, Table 8 shows that for $C L \_3 Y r\left(\right.$ column 3), the coefficient estimate on Disc_Accr $\times H i g h \_E c o n \_C o m p$ is significantly positive. However, when explicitly controlling for financial statement comparability in the same specification (columns 4-6), the coefficient estimate on Disc_Accr $\times$ High_Econ_Comp is insignificant. On the other hand, we continue to find that high financial statement comparability across peer firms helps the SEC to evaluate accounting quality, as evidenced by the coefficient estimate on Disc_Accr $\times$ High_Comp remaining positive and significant. As such, it appears that the role of financial statement comparability in the review process is not fully subsumed by that of economic similarities across firms. That is, it is unlikely that our empirical findings are entirely driven by the underlying economic fundamentals between the firm under review and its peers. ${ }^{25}$

\footnotetext{
${ }^{25}$ We obtain similar results by measuring economic comparability following DKV as the adjusted $\mathrm{R}^{2}$ from regressing a firm's operating cash flows against its peer firm's operating cash flows over the preceding 16 quarters (untabulated).
} 


\subsubsection{Difference-in-Differences Tests}

To further address the concern that DKV's comparability measure is influenced by economic fundamentals, this section explores a quasi-exogenous shock which affects the comparability of accounting numbers but not underlying economics, and examines our prediction without relying on an empirical construct of financial statement comparability (i.e., FSC). In 2007, the SEC ended the requirement that foreign cross-listed firms provide a reconciliation from IFRS to U.S. GAAP if their financial statements were prepared in accordance with IFRS (SEC 2007). Given the additional time and effort needed to integrate accounting numbers across different standards, the mandated reconciliation provided incrementally relevant information when processing multi-firm financial statements. Thus, when the reconciliation requirement was eliminated, the SEC was likely to experience an exogenous reduction in financial statement comparability for these cross-listed IFRS firms relative to cross-listed U.S. GAAP firms. ${ }^{26}$

Utilizing this regulation change, we employ a difference-in-differences design by comparing changes in the likelihood of comment letter issuance for cross-listed 20-F filers that use IFRS both before and after the elimination, relative to the corresponding changes for a control group of cross-listed 20-F filers that do not follow IFRS (i.e., that are not subject to the reconciliation requirement elimination). This design mitigates potential endogeneity concerns related to heterogeneous characteristics across the IFRS (treatment) and non-IFRS (control) groups (Kim, $\mathrm{Li}$, and $\mathrm{Li}$ 2012). Because the regulatory rule change does not affect firms' economic fundamentals, it can help cleanly tease out the effect of financial statements on the SEC's review process.

Table 9 presents the test results where Disc_Accr $\times I F R S \times$ Post captures the effect of the

\footnotetext{
${ }^{26}$ Although firms could still voluntarily provide this reconciliation after the rule change, Kim et al. (2012) find that none of the IFRS firms in their sample did so, suggesting that the rule change impacted these firms' disclosures.
} 
2007 rule change on the SEC's assessment of the treatment group's accounting quality relative to that of the control group. Following Kim et al. (2012), IFRS is equal to one if the cross-listed firm prepares its financial statements under IFRS, and zero otherwise. ${ }^{27}$ Post is equal to one if the firmyear observation is in 2007 , and zero if it is in 2006. Column 2 (CL_Core) reports a negative and significant coefficient estimate on Disc_Accr $\times I F R S \times$ Post, suggesting that the regulation change imposes a negative shock to financial statement comparability that makes the SEC less likely to detect poor accounting quality. ${ }^{28}$

\subsection{Revenue Recognition Comparability}

Our main empirical analysis is conducted at the earnings level and documents that the SEC's issuance of comment letters on accounting and core earnings topics (CL_Acct or CL_Core, respectively) is positively associated with earnings management (Disc_Accr) for firms with high comparability, measured based on the mapping between earnings and returns (High_Comp). This section furthers our analysis by examining revenues, an important accounting choice that is likely a focus of SEC oversight. In his speech, Arthur Levitt, then chairman of the SEC, pointed out revenue recognition as a significant channel through which firms manipulate earnings, reducing the quality and integrity of reported earnings (Levitt 1998). Improper revenue recognition is not only a primary cause of financial restatements (Altamuro, Beatty, and Weber 2005; Audit Analytics 2020), it has also been a key target of the SEC's comment letter review process. ${ }^{29}$

\footnotetext{
${ }^{27}$ We deeply appreciate that the authors of this paper provided us with their hand-collected data identifying the treatment and control groups (i.e., IFRS users vs. non-users). Please refer to Kim et al. (2012) for more details about the sample selection of the levels II and III American Depository Receipt (ADR) companies.

${ }^{28} \mathrm{We}$ also find that on average the SEC is less likely to issue a comment letter to the IFRS users, when compared to non-IFRS users, following the 2007 rule change (untabulated). This is in line with prior studies (e.g., Kedia and Rajgopal 2011; Files 2012) which suggest that the SEC focuses on firms with lower information-processing costs.

${ }^{29}$ Cunningham et al. (2020) identify six types of accounting comments in SEC comment letters using Audit Analytics. They report that $22 \%$ of comments are related to accounts receivables and revenue recognition, more than other accounting types.
} 
We modify DKV's methodology by replacing its original base model, equation (1), with the relation between revenues and expenses (from the previous, current, and next quarters) estimated over 16 (minimum 12) quarters (Dichev and Tang 2008), as follows:

$$
\text { Revenues }_{t}=\omega_{0}+\omega_{1} \text { Expenses }_{t-1}+\omega_{2} \text { Expenses }_{t}+\omega_{3} \text { Expenses }_{t+1}+\varepsilon_{i t} .
$$

The pairwise DKV score computed based on equation (8) is defined as the revenue recognition comparability between two firms. High_Comp_Rev is defined as a dummy variable equal to one if a firm's average of revenue comparability scores relative to its ten most similar-sized industry peers is above the median at the end of the previous year, and zero otherwise. To capture suspicious revenue recognition, which the SEC is likely to be concerned about, we measure discretionary revenues (Disc_Revenue) following Stubben (2010) and abnormal changes in gross account receivables $\left(A b n \_\triangle A R\right)$ and abnormal changes in deferred revenue (Abn_ $\left.\Delta D e f \_R e v\right)$ following Caylor (2010). Consistent with our prediction, Table 10 reveals that the SEC is more likely to issue a revenue-related comment letter (CL_Revenue) to a firm with greater abnormal revenues when the firm's revenue recognition is highly comparable relative to that of its peer firms (columns 1-3). In contrast, for comment letters unrelated to revenue recognition ( $C L \_N o n \_$Revenue), we find no empirical evidence that cross-firm comparability in revenue recognition helps the SEC detect accounting deviations in revenue recognition (columns 4-6). Overall these results reaffirm the regulatory benefits of cross-firm comparable accounting numbers when the SEC assesses a filing firms' revenue recognition decisions. ${ }^{30}$ This narrowing of our analysis helps us establish a clear link between our measures, thereby reducing the concern that our finding is driven by nonaccounting factors.

\footnotetext{
${ }^{30}$ In Appendix 2, we present test results using alternative financial statement comparability measures that modify DKV's algorithm by replacing its original base model (i.e., earnings-return relations) with a series of different base models and find consistent results.
} 


\subsection{Input-based Financial Statement Comparability Measure}

DKV's comparability measure is based on financial reporting outputs (i.e., earnings), and thus has the advantage of not requiring researchers to make empirically challenging decisions about how to collect a broad set of accounting policy choices, or which accounting choice to use and how to weight them. While being easily calculated and generalizable to a large set of firms, DKV's measure does not directly capture the heterogeneity in firm-specific financial reporting inputs (e.g., LIFO vs. FIFO, depreciation method, lease accounting) across firms, which could affect the "mappings" between earnings and returns.

This section explores the robustness of our main finding to an alternative measure of financial statement comparability that aims to directly measure cross-firm consistency of accounting policies. As opposed to DKV that focuses on financial reporting outcomes, Peterson, Schmardebeck, and Wilks (2015) measure input-based accounting consistency (economic comparability) between firms based on the textual similarity in the accounting policy disclosures (the business description disclosure) found in 10-K filings. ${ }^{31}$ Using Peterson et al.'s (2015) measures, we construct High_Input_Comp (High_Input_Econ_Comp), which equals one if a firm's average input-based accounting consistency (economic comparability) scores, relative to all other firms in the same two-digit SIC group are above the annual median, and zero otherwise.

Table 11 re-estimates equation (7) using Peterson et al.’s (2015) input-based comparability measures. Consistent with our hypothesis, we continue to find that the SEC is more likely to issue

\footnotetext{
${ }^{31}$ FASB (2010) states that consistency is the "use of the same methods for the same items, either from period to period within a reporting entity" and that it helps to achieve the goal of comparability. Peterson et al. (2015) highlight that their primitive input-based measures help researchers capture accounting consistency as the FASB defines it, and thus these measures are important alternatives to DKV's output-based measure. We thank Professor Roy Schmardebeck for sharing generously their comparability measures.
} 
a comment letter to a firm with a greater magnitude of abnormal accruals, as evidenced by the coefficient estimate on Disc_Accr $\times$ High_Input_Comp being positive (columns 1 and 3 ) and statistically significant (one-tailed 10\%). In contrast, as evidenced by the insignificant coefficient estimate on Disc_Accr×High_Input_Econ_Comp (columns 4-6), cross-firm comparability in fundamental economics does not significantly affect the SEC's filing review. In columns 7-9, we find that the role of financial statement comparability remains significant after controlling for economic comparability, which is similar to the test results with output-based measures in Table 8. As such, regardless of whether comparability is measured based on accounting inputs or outputs, our empirical findings show that the SEC's filing review is enhanced by cross-firm comparability in accounting systems rather than in underlying economics.

\subsection{Restatement Test}

Our primary empirical results suggest that higher financial statement comparability enables the SEC to better detect a firm's deviations from accounting rules. One concern is that comparability may make all accounting deviations (including those that do not truly reflect noncompliance) more apparent (i.e., type 1 errors). To alleviate this concern, our next test examines whether high financial statement comparability increases the likelihood that comment letters detect more serious accounting non-compliance, which we define as a prior period misstatement that requires a restatement.

We follow Cassell et al. (2013) in modeling the probability that a comment letter leads to a restatement by creating $C L \_A c c t \_$Restatement (CL_Core_Restatement), which equals one if the accounting-related (core earnings-related) comment letter directly results in a restatement, and zero otherwise. We only consider restatements that were filed after the date of the first comment 
letter but before the comment letter dissemination date, as these are the restatements that are most likely to be filed in response to the SEC's comment letter process. Following Kubick (2021), we infer that the comment letter directly leads to the restatement when a topic of the comment letter matches a restatement topic. ${ }^{32}$

To test the likelihood a comment letter identifies a material misstatement, we restrict our analysis to observations in which $C L \_A c c t=1$ and $C L \_C o r e=1$ and examine the association between High_Comp and restatements induced by comment letters (CL_Acct_Restatement, CL_Core_Restatement). Highlighting that higher comparability increases the likelihood the SEC's filing review discovers serious non-compliance issues, Table 12 finds that high financial statement comparability is positively associated with both CL_Acct_Restatement and CL_Core_Restatement. This result reaffirms that comparability facilitates the identification of meaningful accounting deviations.

\subsection{Non-Accounting Comment Letter Issuance}

Table 13 runs falsification tests in which we replicate our main empirical analysis in section 4 using non-accounting-related comment letters as our dependent variable. CL_Non_Acct is equal to one if a firm receives a comment letter that contains no accounting-related topics, and zero otherwise. Since higher financial statement comparability makes it easier for the SEC to understand similarities and differences in accounting performance across peer firms, financial statement comparability would be useful in identifying accounting-related issues, as opposed to non-accounting issues, from $10-\mathrm{K}$ reports. Consistent with this reasoning, using CL_Non_Acct as

\footnotetext{
${ }^{32}$ Kubick (2021) uses Audit Analytics topic keys to match and notes that $89.6 \%$ of the time, the matching results in the same classification as in hand collection. This outcome suggests that this matching procedure accurately captures when restatements were made in response to comment letters.
} 
our dependent variable, we find no evidence supporting our prediction.

Furthermore, this result suggests that our main findings are unlikely to be entirely driven by the selection bias concerns described in Cunningham and Leidner (2020). The concern is that if our variables of interest, poor accounting quality and Comparability, are associated with unobserved SEC review selection criteria, we could observe an association between them and comment letter issuance even if they do not actually impact the discovery of issues during a review (as opposed to influencing the selection of firms to review). Since CL_Acct (or CL_Core) and CL_Non_Acct each capture instances in which the firm's filing was selected for review, both would be subject to the same non-random selection criteria and thus would be affected similarly by selection issues. In turn, these selection bias concerns are lessened by our finding that high financial statement comparability has little association with the SEC's identification of nonaccounting, as opposed to accounting, issues in the filing review process.

\section{CONCLUSION}

We explore the informational value of peer firms in the SEC's filing review process by examining whether regulatory oversight over financial reporting is enhanced by higher financial statement comparability. Consistent with significant regulatory benefits from comparable crossfirm accounting systems, we find that when the firm's financial reporting is more comparable to that of its peers, the SEC is better able to raise a red flag about the firm's accounting deviations suggestive of poor accounting quality. Moreover, further analysis reveals that the role of crossfirm comparable financial reporting in the SEC's evaluation of accounting quality is salient when the SEC faces greater monitoring constraints. This outcome highlights the information channel through which comparable benchmarks facilitate regulatory oversight. 
Collectively, our study provides novel evidence that higher financial statement comparability enhances the efficacy of the SEC's oversight over corporate disclosure by reducing the information costs inherent to filing reviews. Our findings are especially relevant to the SEC given their recent efforts to improve the efficiency of the filing review process. Nevertheless, given that firms' accounting decisions are unlikely to be independent of their fundamentals, we cannot completely rule out the possibility that our results, which are based on DKV's comparability measure, are influenced by economic similarities. While we perform an extensive set of robustness tests, our results should nevertheless be interpreted with this caution in mind. 


\section{References}

Albuquerque, A. 2009. Peer firms in relative performance evaluation. Journal of Accounting and Economics 48 (1): 69-89.

Altamuro, J., A. L. Beatty, and J. Weber 2005. The effects of accelerated revenue recognition on earnings management and earnings informativeness: Evidence from SEC Staff Accounting Bulletin No. 101. The Accounting Review 80 (2): 373-401.

Altman, E. I. 1968. Financial ratios, discriminant analysis and the prediction of corporate bankruptcy. The Journal of Finance 23 (4): 589-609.

Audit Analytics. 2020. 2019 financial restatements: A nineteen year comparison report, https://blog.auditanalytics.com/2019-financial-restatements-review/

Barth, M. E., W. R. Landsman, and M. H. Lang. 2008. International accounting standards and accounting quality. Journal of Accounting Research 46 (3): 467-98.

Barth, M. E., W. R. Landsman, W. R., M. Lang, and C. Williams. 2012. Are IFRS-based and US GAAP-based accounting amounts comparable? Journal of Accounting and Economics 54 (1): 68-93.

Barton, J., T. B. Hansen, and G. Pownall. 2010. Which performance measures do investors around the world value the most-and why? The Accounting Review 85 (3): 753-89.

Basu, S. 1997. The conservatism principle and the asymmetric timeliness of earnings. Journal of Accounting and Economics 24(1): 3-37.

Bhattacharya, N., Y. J. Cho, and J. B. Kim. 2018. Leveling the playing field between large and small institutions: Evidence from the SEC's XBRL mandate. The Accounting Review 93 (5): 51-71.

Blackburne, T. P. 2014. Regulatory oversight and financial reporting incentives: Evidence from the SEC budget allocations. Working paper.

Bradshaw, M.T., G. S. Miller, G. and Serafeim. 2009. Accounting method heterogeneity and analysts' forecasts. Working paper.

Campbell, J. L., and P. E. Yeung. 2017. Earnings comparability, accounting similarities, and stock returns: Evidence from peer firms' earnings restatements. Journal of Accounting, Auditing, and Finance 32 (4): 480-509.

Cascino, S., and J. Gassen. 2015. What drives the comparability effect of mandatory IFRS adoption? Review of Accounting Studies 20 (1): 242-82.

Cassell, C. A., L. M. Dreher, and L. A. Myers. 2013. Reviewing the SEC's review process: 10-K comment letters and the cost of remediation. The Accounting Review 88 (6): 1875-1908.

Caylor M. L. 2010. Strategic revenue recognition to achieve earnings benchmarks. Journal of Accounting and Public Policy 29 (1): 82-95.

Chen, C.-W., D. W. Collins, T. D. Kravet, and R. D. Mergenthaler. 2018. Financial statement comparability and the efficiency of acquisition decisions. Contemporary Accounting Research 35 (1): 164-202.

Chen, S., B. Miao, and T. Shelvin. 2015. A new measure of disclosure quality: The level of disaggregation of accounting data in annual reports. Journal of Accounting Research 53 (5): 1017-54.

Choi, J.-H., S. A. Choi, L. A. Myers, and D. Ziebart. 2019. Financial statement comparability and the informativeness of stock prices. Contemporary Accounting Research 36 (1): 389417.

Collins, D. W., S.P. Kothari, J. Shanken, and R. G. Sloan. 1994. Lack of timeliness and noise as 
explanations for the low contemporaneous return-earnings association. Journal of Accounting and Economics 18: 289-324.

Cunningham, L. M., B. A. Johnson, S. E. Johnson, and L. L. Lisic. 2020. The switch-up: An examination of changes in earnings management after receiving SEC comment letters. Contemporary Accounting Research 37 (2): 917-44.

Cunningham, L. M., and J. J. Leidner. 2020. The SEC filing review process: Insights from accounting research. Working paper.

Dechow, P. M., and I. D. Dichev. 2002. The quality of accruals and earnings: The role of accruals estimation errors. The Accounting Review 77 (Supplement): 35-59.

Dechow, P., W. Ge, and C. Schrand. 2010. Understanding earnings quality: A review of the proxies, their determinants and their consequences. Journal of Accounting and Economics 50 (2-3): 344-401.

De Franco, G., S.P. Kothari, and R. S. Verdi. 2011. The benefits of financial statement comparability. Journal of Accounting Research 49 (4): 895-931.

Dhaliwal, D., V. Naiker, and F. Navissi. 2010. The association between accruals quality and the characteristics of accounting experts and mix of expertise on audit committees. Contemporary Accounting Research 27 (3): 787-827.

Dichev, I. D., and V. W. Tang. 2008. Matching and the changing properties of accounting earnings over the last 40 years. The Accounting Review 83 (6): 1425-60.

Dichev, I. D., and V. W. Tang. 2009. Earnings volatility and earnings predictability. Journal of Accounting and Economics 47: 160-181.

Doyle, J. T., W. Ge, and S. McVay. 2007. Accruals quality and internal control over financial reporting. The Accounting Review 85 (5): 1141-70.

Ege, M., J. L. Glenn, and J. R. Robinson. 2020. Unexpected SEC resource constraints and comment letter quality. Contemporary Accounting Research 37 (1): 33-67.

Elliott, J.A., and J. D. Hanna. 1996. Repeated accounting write-offs and the information content of earnings. Journal of Accounting Research 34 (Supplement): 135-55.

Fama, E. F., and K. R. French. 1997. Industry costs of equity. Journal of Financial Economics 43 (2): 153-93.

Fang, V.W., M. Iselin, and G. Zhang. 2017. Financial statement comparability: Benefits and costs. Working paper.

FASB (Financial Accounting Standards Board). 2010. Conceptual Framework for Financial Reporting: Statement of Financial Accounting Concepts No. 8.

Files, R. 2012. SEC enforcement: Does forthright disclosure and cooperation really matter? Journal of Accounting and Economics 53 (1-2): 353-74.

Francis, J., R. LaFond, P. Olsson, and K. Schipper. 2005. The market pricing of accruals quality. Journal of Accounting and Economics 39 (2): 295-327.

Grove, H., T. Johnsen, and P. Lung. 2016. SEC comment letters: An unlikely secret weapon for forensic accountants, short sellers, and other financial statement users. Journal of Forensic and Investigative Accounting 8 (2): 179-96.

Gunny, K.A., and J. M. Hermis. 2020. How busyness influences SEC compliance activities: Evidence from the filing review process and comment letters. Contemporary Accounting Research 37 (1): 7-32.

Hagerman, R.L., and M. E. Zmijewski, M.E. 1979. Some economic determinants of accounting policy choice. Journal of Accounting and Economics 1: 141-61.

Heese, J., M. Khan, and K. Ramanna. 2017. Is the SEC captured? Evidence from comment-letter 
reviews. Journal of Accounting and Economics 64 (1): 98-122.

Heitzman, S., C. Wasley, and J. Zimmerman. 2010. The joint effects of materiality thresholds and voluntary disclosure incentives on firms' disclosure decisions. Journal of Accounting and Economics 49 (1-2): 109-32.

Hope, O.-K., W. B. Thomas, and D. Vyas. 2013. Financial reporting quality of U.S. private and public firms. The Accounting Review 88 (5): 1715-42.

Hribar, P., T. Kravet, and R. Wilson. 2014. A new measure of accounting quality. Review of Accounting Studies 19 (1): 506-38.

Johnston, R., and R. Petacchi. 2017. Regulatory oversight of financial reporting: Securities and Exchange Commission comment letters. Contemporary Accounting Research 34 (2): 112855.

Jones, J.J. 1991. Earnings management during import relief investigations. Journal of Accounting Research 29 (2); 193-228.

Kedia, S., and S. Rajgopal. 2011. Do the SEC's enforcement preferences affect corporate misconduct? Journal of Accounting and Economics 51 (3): 259-78.

Kim, Y., H. Li, and S. Li. 2012. Does eliminating the form 20-F reconciliation from IFRS to US GAAP have capital market consequences? Journal of Accounting and Economics 53 (1-2): 249-70.

Kim, J.-B., L. Li, L. Y. Lu, and Y. Yu. 2016. Financial statement comparability and expected crash risk. Journal of Accounting and Economics 61 (2-3): 294-312.

Kim, S., P. Kraft, and S. G. Ryan. 2013. Financial statement comparability and credit risk. Review of Accounting Studies 18 (3): 783-823.

Kothari, S.P., A. J. Leone, and C. E. Wasley. 2005. Performance matched discretionary accrual measures. Journal of Accounting and Economics 39 (1): 163-97.

Kubick, M. 2021. Examining the examiners: SEC error detection rates and human capital allocation. The Accounting Review 96 (3): 313-41.

Lee, C. M.C., P. Ma, and C. C.Y. Wang. 2015. Search based peer firms : Aggregating investor perceptions through internet searches. Journal of Financial Economics 116 (2): 410-31.

Levitt, A.1998. The "Numbers Game." Speech delivered at the NYU Center for Law and Business, September 28, New York, NY, https://www.sec.gov/news/speech/speecharchive/1998/spch220.txt.

Lewis, C.M., 2012. Risk Modeling at the SEC: The Accounting Quality Model. December 13, https://www.sec.gov/news/speech/2012-spch121312cmlhtm.

Lobo, G. J., M. Neel, and A. Rhodes. 2018. Accounting comparability and relative performance evaluation in CEO compensation. Review of Accounting Studies 23 (3): 1137-76.

Nam, J. 2020. Financial reporting comparability and accounting-based relative performance evaluation in the design of CEO cash compensation contracts. The Accounting Review 95 (3): 343-70.

Norton, E.C., H. Wang, and C. Ai. 2004. Computing interaction effects and standard errors in logit and probit models. The Stata Journal 4 (2): 154-67.

Palmrose, Z.-V., and S. Scholtz. 2004. The circumstances and legal consequences of non-GAAP reporting: Evidence from restatements. Contemporary Accounting Research 21 (1): 139-80.

Peterson, K., R. Schmardebeck, and T. J. Wilks. 2015. The earnings quality and information processing effects of accounting consistency. The Accounting Review 90 (6): 2483-2514.

Ramnath, S. 2002. Investor and analyst reactions to earnings announcements of related firms: An empirical analysis. Journal of Accounting Research 40 (5): 1351-76. 
SEC (Securities and Exchange Commission). 2007. Acceptance from foreign private issuers of financial statements prepared in accordance with International Financial Reporting Standards without reconciliation to U.S. GAAP. Release No. 33-8879, https://www.sec.gov/rules/final/2007/33-8879.pdf

SEC (Securities and Exchange Commission). 2009. Interactive data to improve financial reporting, Release No. 33-9002, http://www.sec.gov/rules/final/2009/33-9002.pdf

SEC (Securities and Exchange Commission). 2019a. Division of Corporation Finance filing review process. http://www.sec.gov/divisions/corpfin/cffilingreview.htm, accessed on March 25, 2019.

SEC (Securities and Exchange Commission). 2019b. Fiscal year 2020 congressional budget justification and annual performance plan; Fiscal year 2018 annual performance report, https://www.sec.gov/files/secfy20congbudgjust_0.pdf

Sohn, B. C. 2016. The effect of accounting comparability on the accrual-based and real earnings management. Journal of Accounting and Public Policy 35 (5): 513-39.

Stubben, S. R. 2010. Discretionary revenues as a measure of earnings management. The Accounting Review 85 (2): 695-717.

US (United States) Senate. Staff of the Committee on Governmental Affairs. 2002. Financial oversight of Enron: The SEC and private-sector watchdogs. Washington, D.C.: Government Printing Office.

Watts, R.L., and J. L. Zimmerman. 1990. Positive accounting theory : A ten year perspective. The Accounting Review 65 (1): 131-56.

Zhang, J. H. 2018. Accounting comparability, audit effort, and audit outcomes. Contemporary Accounting Research 35 (1): 245-76. 


\section{Appendix 1 - Variable Definitions}

\begin{tabular}{|c|c|}
\hline Variable & Definition \\
\hline$C L \_A c c t$ & $\begin{array}{l}\text { A dummy variable equal to one if the firm received a comment letter on its } 10-\mathrm{K} \\
\text { filing for the fiscal year } \mathrm{t} \text { and the topic of the comment letter relates to an } \\
\text { accounting rule or accounting disclosure issue } \\
\text { (i.e., LIST_OF_TAXON="Accounting Rule and Accounting Disclosure Type } \\
\text { Issues"), and zero otherwise. }\end{array}$ \\
\hline CL_Core & $\begin{array}{l}\text { A dummy variable equal to one if the firm received a comment letter on its 10-K } \\
\text { filing for the fiscal year t and the topic of the comment letter relates to a core } \\
\text { earnings issue and zero otherwise. We follow Cassell et al. (2013) to identify the } \\
\text { following Audit Analytics' topic codes as "core" earnings topics: } 176 \text { Accounts } \\
\text { receivable and cash reporting issues. } 190 \text { Depreciation, depletion, or amortization } \\
\text { reporting issues, } 192 \text { Expense (payroll, selling, general, and administrative, and } \\
\text { other) recording issues, } 202 \text { Inventory, vendor, and/or cost of sales issues, } 204 \\
\text { Lease, leasehold (FAS } 13 \text { (98) and IAS 17), } 205 \text { Liabilities, payables, and accrual } \\
\text { estimate issues, } 212 \text { Revenue recognition (including deferred revenue) issues, } 816 \\
\text { Percentage of completion, and } 1016 \text { Research and development issues. }\end{array}$ \\
\hline$C L \_3 Y r$ & $\begin{array}{l}\text { A dummy variable equal to one if the company received a comment letter } \\
\text { (according to Audit Analytics) on its } 10-\mathrm{K} \text { filing for the fiscal year } \mathrm{t} \text {, and zero if } \\
\text { the company did not receive a } 10-\mathrm{K} \text { comment letter in year } \mathrm{t}, \mathrm{t}-1 \text {, or } \mathrm{t}-2 \text {, following } \\
\text { Cassell et al. (2013). }\end{array}$ \\
\hline Comparability & $\begin{array}{l}\text { The average of financial statement comparability (FSC) between a focal firm and } \\
\text { its top } 10 \text { similar-sized peer firms from the same industry (SIC two digit). FSC } \\
\text { between two firms is measured following DKV (see section 3.2). }\end{array}$ \\
\hline High_Comp & $\begin{array}{l}\text { A dummy variable that equals one if the firm's measure of Comparability at the } \\
\text { end of the previous year is above the annual sample median, and zero otherwise. }\end{array}$ \\
\hline Disc_Accr & $\begin{array}{l}\text { The absolute value of discretionary accruals, which is measured using the modified } \\
\text { cross-sectional Jones model (Jones 1991) estimated for each two-digit SIC-year } \\
\text { groupings as follows: } \\
T A_{i t} / \text { Assets }_{i, t-1} \\
=k_{1}\left(1 / \text { Assets }_{i, t 1}\right)+k_{2}\left(\left(\Delta R E V_{i t}-\Delta A R_{i t}\right) / \text { Assets }_{i, t-1}\right)+k_{3}\left(P P E_{i t} / A s s e t s_{i, t-1}\right)+\varepsilon_{i t} \\
\text {, where using Compustat, } T A \text { (total accruals) }=\mathrm{EBXI-CFO;} \Delta R E V \text { is the change in } \\
\text { revenues (SALE); } \triangle A R \text { is the change in accounts receivable (RECT); PPE is } \\
\text { PPEGT. }\end{array}$ \\
\hline$M \& A$ & $\begin{array}{l}\text { A dummy variable equal to one for non-zero acquisitions or mergers as reported } \\
\text { on a pre-tax basis (Compustat: AQP), and zero otherwise. }\end{array}$ \\
\hline High Volatility & $\begin{array}{l}\text { A dummy variable equal to one if the standard deviation of stock returns (CRSP: } \\
\text { RET) measured over the } 36 \text { months prior to the fiscal year end is in the highest } \\
\text { quartile for a given fiscal year, and zero otherwise. }\end{array}$ \\
\hline $\log ($ Mkt Cap $)$ & $\begin{array}{l}\text { The natural log of one plus the number of outstanding shares at the fiscal year-end } \\
\text { (Compustat: CSHO) times the fiscal year-end share price (Compustat: PRCC_F). }\end{array}$ \\
\hline Firm Age & Firm age since its first appearance in Compustat. \\
\hline Loss & $\begin{array}{l}\text { A dummy variable equal to one if earnings before extraordinary items (Compustat: } \\
\text { IB) is negative, and zero otherwise. }\end{array}$ \\
\hline Bankruptcy & $\begin{array}{l}\text { The decile rank of the firm's Altman's Z-score, } 1 \text { (10) for highest (poorest) } \\
\text { financial health. Using Compustat, we calculate Altman's Z-score as } 1.2^{*}(\mathrm{ACT}- \\
\mathrm{LCT}) / \mathrm{AT}+1.4^{*} \mathrm{RE} / \mathrm{AT}+3.3^{*}(\mathrm{PI}+\mathrm{XINT}) / \mathrm{AT}+0.6^{*}(\mathrm{CSHO}- \\
\text { PRCC_F)/LT+1*SALE/AT, following Altman }(1968) \text { and Cassell et al. (2013). }\end{array}$ \\
\hline External Financing & $\begin{array}{l}\text { The sum of equity and debt financing scaled by total assets, measured in year } t+1 \text {. } \\
\text { Equity financing equals the sales of common and preferred stock (SSTK) minus } \\
\text { the purchase of common and preferred stock (PRSTKC) minus dividends (DV). } \\
\text { Debt financing equals long-term debt issued (DLTIS) minus long-term debt } \\
\text { reduction (DLTR) minus the change in current debt (DLCCH). }\end{array}$ \\
\hline
\end{tabular}




\begin{tabular}{|c|c|}
\hline Big4 & $\begin{array}{l}\text { A dummy variable equal to one if the firm's auditor in year t is a Big } 4 \text { audit firm, } \\
\text { and zero otherwise (Compustat: AU) }\end{array}$ \\
\hline Second Tier & $\begin{array}{l}\text { A dummy variable equal to one if the firm's auditor in year } \mathrm{t} \text { is a second-tier audit } \\
\text { firm (i.e., BDO, Crowe, Grant Thornton, or RSM) and zero otherwise. } \\
\text { (Compustat: AU) }\end{array}$ \\
\hline Stock Correlation & $\begin{array}{l}\text { The stock return correlation between a firm and its industry peers (2-digit SIC) } \\
\text { over } 48 \text { months. }\end{array}$ \\
\hline Stock Synchronicity & $\begin{array}{l}\text { The adjusted } \mathrm{R}^{2} \text { from a regression of a firm's daily stock return on the daily } \\
\text { market return over } 48 \text { months. }\end{array}$ \\
\hline Abs Special Items & The absolute value of special items (Compustat: SPI) scaled by total assets. \\
\hline Prior Restate & $\begin{array}{l}\text { A dummy variable equal to one if the firm filed a restatement during fiscal years } \\
\mathrm{t}, \mathrm{t}-1 \text {, or } \mathrm{t}-2 \text { according to the Audit Analytics Restatement dataset, and zero } \\
\text { otherwise. }\end{array}$ \\
\hline SEC Resources & $\begin{array}{l}\text { The annual number of industry-level } \mathrm{AD} \text { office employees divided by the market } \\
\text { value in billions of Compustat firms assigned to that corresponding AD office. }\end{array}$ \\
\hline High_Econ_Comp & $\begin{array}{l}\text { A dummy variable equal to one if the firm's average scores for economic } \\
\text { comparability (relative to the ten most similar-sized industry peer firms) is greater } \\
\text { than the annual median, and zero otherwise. The scores are measured by the } \\
\text { modified DKV methodology, which uses the cash flows-returns relation as the } \\
\text { base model following Chen et al. (2018). }\end{array}$ \\
\hline IFRS & $\begin{array}{l}\text { A dummy variable equal to one if the cross-listed firms prepares their financial } \\
\text { statements under IFRS, and zero otherwise, following Kim et al. (2012). }\end{array}$ \\
\hline Post & $\begin{array}{l}\text { A dummy variable equal to one if the firm-year observation is in } 2007 \text {, and zero if } \\
\text { it is in } 2006 \text {, following Kim et al. (2012). }\end{array}$ \\
\hline $\begin{array}{l}\text { CL_Revenue } \\
\text { (CL_Non_Revenue) }\end{array}$ & $\begin{array}{l}\text { A dummy variable equal to one if the firm received a comment letter on its } 10-\mathrm{K} \\
\text { filing for the fiscal year } \mathrm{t} \text { and the topic of the comment letter relates (did not relate) } \\
\text { to revenue, and zero otherwise. We consider Audit Analytics' topic code } 212 \\
\text { "Revenue recognition (including deferred revenue) issues" to relate to revenue. }\end{array}$ \\
\hline High_Revenue_Comp & $\begin{array}{l}\text { A dummy variable equal to one if the firm's average scores for revenue- } \\
\text { recognition comparability (relative to the ten most similar-sized industry peer } \\
\text { firms) are greater than the annual median, and zero otherwise The scores are } \\
\text { measured by the modified DKV methodology, which uses the revenues-expenses } \\
\text { relation (as illustrated in Dichev and Tang 2008) as the base model. }\end{array}$ \\
\hline Disc_Revenue & $\begin{array}{l}\text { Discretionary revenues as the residual from industry-year-level regressions of } \\
\text { annual changes in accounts receivables against annual changes in revenues (the } \\
\text { first three quarters) and the annual changes in revenues (the fourth quarter), } \\
\text { following Stubben (2010). }\end{array}$ \\
\hline$A b n \_\triangle A R$ & Abnormal change in gross accounts receivable, following Caylor (2010). \\
\hline$A b n \_\Delta D e f \_R e v$ & Abnormal change in short-term deferred revenue, following Caylor (2010). \\
\hline High_Input_Comp & $\begin{array}{l}\text { A dummy variable equal to one if the firm's input-based financial statement } \\
\text { comparability is greater than the annual median, and zero otherwise. Input-based } \\
\text { financial statement comparability is measured based on textual similarities of the } \\
\text { accounting disclosure policy from 10-K reports relative to industry peers (Peterson } \\
\text { et al. 2015). }\end{array}$ \\
\hline High_Input_Econ_Comp & $\begin{array}{l}\text { A dummy variable equal to one if the firm's input-based economic comparability } \\
\text { is greater than the annual median, and zero otherwise. Input-based economic } \\
\text { comparability is measured based on textual similarities of the business description } \\
\text { from } 10-\mathrm{K} \text { reports relative to industry peers (Peterson et al. 2015). }\end{array}$ \\
\hline $\begin{array}{l}\text { CL_Acct_Restatement } \\
\left(C L \_C o r e \_ \text {Restatement }\right)\end{array}$ & $\begin{array}{l}\text { A dummy variable that equals one if an accounting-related (core earnings-related) } \\
\text { comment letter directly resulted in a restatement and zero if it did not. We consider } \\
\text { a comment letter to directly result in a restatement if the firm restated its financial } \\
\text { statements after the first comment letter but before the comment letter } \\
\text { dissemination date and a topic in the comment letter matches a topic of the } \\
\text { restatement (following the matching provided in Kubick (2021)). }\end{array}$ \\
\hline
\end{tabular}




\begin{tabular}{l|l}
\hline Num Topics & $\begin{array}{l}\text { Number of topics addressed in the comment letter conversation according to Audit } \\
\text { Analytics' "LIST_OF_TAXON." }\end{array}$ \\
\hline Filings & $\begin{array}{l}\text { The number of filings (e.g., 10-K, 10-Q, 8-K) referenced in the comment letter } \\
\text { according to Audit Analytics' "LIST_FORM_DATES." }\end{array}$ \\
\hline CL_Non_Acct & $\begin{array}{l}\text { A dummy variable equal to one if the firm received a comment letter on its 10-K } \\
\text { filing for the fiscal year t and the topic of the comment letter does NOT relate to } \\
\text { an accounting rule or accounting disclosure issue (i.e., LIST_OF_TAXON does } \\
\text { not include "Accounting Rule and Accounting Disclosure Type Issues"), and zero } \\
\text { otherwise. }\end{array}$ \\
\hline
\end{tabular}




\section{Appendix 2 - Robustness Checks with Alternative Variable Specifications}

\section{Alternative Measures of Accounting Quality}

Tables A2-1 and A2-2 respectively present how robust our baseline test from Table 4 (estimated using equation (6)) and our main prediction from Table 5 (estimated using equation (7)) are to alternative accounting quality measures. First, we recalculate discretionary accruals using three alternative models as illustrated in Kothari et al. (2005): the Jones model, the Jones model including ROA, and the modified Jones model including ROA. Panel A in both Tables A2-1 and A2-2 show that these alternative discretionary accruals measure produce results that are similar to our main analysis.

Second, in panel B in both Tables A2-1 and A2-2, we include three alternative proxies for poor accounting quality, Std(ROA), Accruals Quality, and Unexplained Audit Fees. Columns 1-3 in each panel show the results with the standard deviation ROA, defined as earnings before extraordinary items (IBQ) scaled by total assets (ATQ), over the preceding 16 quarters. High earnings volatility lowers the relevance of earnings (Elliott and Hanna 1996) and reduces investors' ability to project a firm's future performance (Barton, Hansen, and Pownall 2010). As such, prior studies often associate highly volatile earnings with poor accounting quality (Dichev and Tang 2009; Hope, Thomas, and Vyas 2013). When using Std(ROA) to capture poor accounting quality, in our baseline results, we find that the SEC is actually less likely to issue comment letters to poor accounting quality as evidenced by the negative coefficient on $\operatorname{Std}(R O A)$ in Table A2-1. However, our main predicted effect, captured by the interaction term in equation (7), is positive and highly significant (at the $1 \%$ level) when using $\operatorname{Std}(R O A)$.

Columns 4-6 of panel B include Accruals Quality using the Dechow and Dichev (2002) model, augmented with the fundamental variables (PPE and change in revenues) from the modified Jones model as our poor accounting quality proxy. We estimate the following equation (A2) for each of Fama and French's (1997) 48 industry groups with at least 20 firms in year t.

$$
\begin{aligned}
\Delta W C_{i t} / \text { Assets }_{i t}= & \theta_{0}+\theta_{1}\left(\text { CFO }_{i, t-1} / \text { Assets }_{i t}\right)+\theta_{2}\left(\text { CFO }_{i t} / \text { Assets }_{i t}\right)+\theta_{3}\left(\text { CFO }_{i, t+1} / \text { Assets }_{i t}\right) \\
& +\theta_{4}\left(\Delta R E V_{i t} / \text { Assets }_{i t}\right)+\theta_{5}\left(P P E_{i t} / \text { Assets }_{i t}\right)+v_{i t},
\end{aligned}
$$

where $\triangle W C$ is change in working capital, CFO is operating cash flow, $\triangle R E V$ is the change in revenues from the preceding year, and $P P E$ is property, plant, and equipment, as defined in Francis, LaFond, Olsson, and Schipper (2005). The annual cross-sectional estimation of (A2-1) obtains firm-year-specific residuals. Accruals Quality is the standard deviation of $v_{i t}$, calculated over years t-4 through t. Dechow and Dichev (2002) posit that high-quality accruals are eventually realized as cash flows. That is, poorly estimated accruals are less likely to be realized as cash flows, which undermines the informativeness of accounting numbers. Consistent with the information risk embedded in accruals quality, Francis et al. (2005) show that poorer Accruals Quality is associated with larger costs of capital. Furthermore, prior studies document that poor accruals quality is associated with the firm-specific monitoring and oversight characteristics that concern regulators such as internal control weaknesses (Doyle, Ge, and McVay 2007) and less effective audit committees (Dhaliwal, Naiker, and Navissi 2010). Using Accruals Quality as our accounting quality proxy, we find some evidence that the SEC is more likely to issue comment letters to firms with low accounting quality, indicated by the positive coefficient on Accruals Quality in Table A2-1, panel B, column (5). As for our main test, the coefficient on Accruals Quality x High Comp remains positive and significant in Table A2-2, panel B, columns (4)-(6), further confirming our prediction. 
Last, in columns 7-9 of panel B, we confirm our prior results when measuring accounting quality as unexplained audit fees. Hribar et al. (2014) argue that auditors price poor quality accounting, and thus the portion of audit fees unexplained by other audit fee determinants is likely to capture poor accounting quality. Following Hribar et al. (2014), we estimate Unexplained Audit Fees as the residual from the size decile-year-specific regressions of the log of audit fees on its determinants. ${ }^{33}$ Overall, our results are robust to using alternative accounting quality proxies.

\section{Alternative Measures of Financial Statement Comparability}

In this section, we explore alternative base models for DKV's methodology to measure financial statement comparability. First, similar to Cascino and Gassen (2015) and Nam (2020), we replace DKV's base model, equation (1), with the firm-level accruals-cash flow relations over the previous 16 (minimum 12) quarters as follows.

$$
\text { Accruals }_{i t}=\alpha_{i}+\beta_{i 1} \mathrm{CFO}_{i t-1}+\beta_{i 2} \mathrm{CFO}_{i t}+\beta_{i 3} \mathrm{CFO}_{i t+1}+\varepsilon_{i t} \text {. }
$$

The variables are scaled by lagged total assets and defined in Dechow and Dichev (2002). Since the DKV measure is based on the earnings-return relation, it might be affected by factors unrelated to the accounting system. Relying on direct outputs of financial reporting decisions, the mapping of accruals into cash flows (A2-2) highlights the effect of accounting factors on cross-firm financial statement comparability.

Second, following DKV, we alternatively measure financial statement comparability by estimating the following time-series equation over the previous 16 (minimum 12) quarters.

$$
\text { Earnings }_{i t}=\alpha_{i}+\beta_{1 i} \text { Return }_{i t}+\beta_{2 i} \text { Return }_{i t-1}+\varepsilon_{i t}
$$

where Return $_{i t-1}$ is the prior-quarter stock returns. DKV's measure of financial statement comparability is based on the implicit assumption that the rate at which economic information is incorporated into price is the same across firm pairs. However, factors outside of a firm's financial reporting (e.g., institutions and financial analysts) could influence this rate differently for different firms. That is, even if two firms are equally timely in reporting earnings, they could be classified as less comparable in financial reporting because of non-accounting factors. Measuring DKV's method based on equation (A2-3) alleviates this concern by allowing prices to incorporate firmspecific news before accounting earnings, that is, "prices lead earnings" (e.g., Collins, Kothari, Shanken, and Sloan 1994).

Third, following Campbell and Yeung (2017) and Chen et al. (2018), we re-estimate DKV's method by using the following time-series equation of over the previous 16 (minimum 12) to incorporate asymmetric timeliness into our comparability measure (Basu 1997).

$$
\text { Earnings }_{i t}=\alpha_{i}+\beta_{1 i} \text { Return }_{i t}+\beta_{2 i} \text { Neg }_{i t}+\beta_{3 i} \text { Return }_{i t} \times N e g_{i t}+\varepsilon_{i t},
$$

where Neg is a dummy variable equal to one if Return is negative and zero otherwise.

Finally, we also calculate two financial statement comparability measures adapted from Barth, Landsman, Lang, and Williams (2012). In estimating the DKV method, we run the following time-series equations using the previous 16 (minimum 12) quarters (Chen et al. 2018).

$$
\text { Returns }_{i t}=\alpha_{i}+\beta_{1 i}\left(N I_{i t} / P_{i t-1}\right)+\beta_{2 i}\left(\Delta N I_{i t} / P_{i t-1}\right)+\beta_{3 i} \text { Loss }_{i t}
$$

\footnotetext{
${ }^{33}$ Namely, our determinants and their measurements mirror those included in Hribar et al. (2014): big four auditor indicator, the log of assets, the square root of business segments, the ratio of foreign sales to total sales, inventory scaled by total assets, receivables scaled by total assets, the current ratio, the book to market ratio, leverage, the square root of the number of employees, a merger indicator, a December year end indicator, ROA, a loss indicator, a modified audit opinion indicator, the square root of auditor tenure, an IPO indicator, an SEO indicator, an issuance of public debt indicator, a high litigation industry indicator, and industry dummy variables.
} 


$$
\begin{aligned}
& +\beta_{4 i} \operatorname{Loss}_{i t} \times\left(N I_{i t} / P_{i t-l}\right)+\beta_{2 i} \operatorname{Loss}_{i t} \times\left(\Delta N I_{i t} / P_{i t-1}\right)+\varepsilon_{i t} \\
& P_{i t}=\alpha_{i}+\beta_{1 i} * B V E_{i t}+\beta_{2 i} * N I_{i t}+\varepsilon_{i t},
\end{aligned}
$$

where $N I$ is net income before extraordinary items per share. Loss is a dummy variable equal to one if $N I$ is negative, and zero otherwise. $P$ is the stock price ( $>10$ in equation (A2-6) to mitigate the estimation outliers), and $B V E$ is the book value of equity per share.

Using those five alternative base models of accounting systems, we follow the DKV algorithm to measure the distance between firms' accounting functions to create our alternative measures of financial statement comparability. Based on the accruals-cash flow mapping of equation (A2-2), High_Comp_DD is defined as a dummy variable equal to one if a firm's average financial statement comparability scores relative to the ten most similar-sized industry peers is greater than the annual median in the prior year, and zero otherwise. High_Comp_PLE, High_Comp_BASU,High_Comp_BLLW1, and High_Comp_BLLW2 are analogously measured using equations (A2-3), (A2-4), (A2-5), and (A2-6), respectively. The results from using these alternative comparability measures are presented in Table A2-3. Our inferences remain unchanged for four out of the five alternative measures. 
TABLE 1

Sample Construction

Panel A: Sample Selection Process

Firm-years with matching Compustat and Audit Analytics identifiers fiscal years 2004-2016

Less: Ambiguous or missing CRSP information (keep CRSP code shrcd 10 or 11)

Less: SEC AD office unidentified

Less: Missing data for measuring financial statement comparability (DKV)

Less: Missing other variables

Final sample (firm-year)

Panel B: Sample Distribution by AD Office

\begin{tabular}{lcccc}
\hline Industry group & AD Office & $\mathrm{N}$ & Percent & Cum. \\
\hline Health Care and Insurance & 1 & 2,465 & 10.24 & 10.24 \\
Consumer Products & 2 & 2,354 & 9.78 & 20.02 \\
Computers and On Line Svcs & 3 & 3,034 & 12.6 & 32.62 \\
Natural Resources and Food & 4 & 1,871 & 7.77 & 40.39 \\
Transportation and Leisure & 5 & 2,916 & 12.11 & 52.5 \\
Manuf. and Construction & 6 & 3,492 & 14.5 & 67.01 \\
Financial Services & 7 & 65 & 0.27 & 67.28 \\
Real Estate and Bus Svcs & 8 & 395 & 1.64 & 68.92 \\
Bev, Apparel, Health Care Svcs & 9 & 1,477 & 6.13 & 75.05 \\
Electronics and Machinery & 10 & 4,066 & 16.89 & 91.94 \\
Telecommunications & 11 & 1,940 & 8.06 & 100 \\
\hline
\end{tabular}

Note: We exclude the following industries (SIC code); Federal \& Federally-Sponsored Credit Agencies (6111), Security Brokers, Dealers \& Flotation Companies (6211), Investment Advice (6282), American Depository Receipts (8880), Foreign Governments (8888), International Affairs (9721), Services-Business Services (7389), Commercial Banks (6029), Blank Checks (6770), Non-Operating Establishments (9995), and Asset-Backed Securities (6189). 
TABLE 2

Summary Statistics

Panel A: Pooled Sample (N=24,075)

\begin{tabular}{lccccc}
\hline Variable & Mean & Std Dev & Q1 & Median & Q3 \\
\hline CL_Acct & 0.273 & 0.445 & 0 & 0 & 1 \\
CL_Core & 0.158 & 0.365 & 0 & 0 & 0 \\
CL_3Yr $(\mathrm{N}=14,013)$ & 0.581 & 0.493 & 0 & 0 & 1 \\
Comparability & -0.036 & 0.039 & -0.042 & -0.022 & -0.013 \\
High_Comp & 0.500 & 0.500 & 0 & 1 & 1 \\
Disc_Accr & 0.071 & 0.092 & 0.017 & 0.04 & 0.085 \\
M\&A & 0.191 & 0.393 & 0 & 0 & 0 \\
High Volatility & 0.25 & 0.433 & 0 & 0 & 0 \\
Log(Mkt Cap) & 6.431 & 2.065 & 4.946 & 6.436 & 7.864 \\
Firm Age & 22.006 & 14.959 & 10 & 18 & 32 \\
Loss & 0.293 & 0.455 & 0 & 0 & 1 \\
Bankruptcy & 4.497 & 2.871 & 2 & 4 & 7 \\
External Financing & 0.010 & 0.162 & -0.058 & -0.011 & 0.030 \\
Big4 & 0.756 & 0.429 & 1 & 1 & 1 \\
Second Tier & 0.120 & 0.324 & 0 & 0 & 0 \\
Stock Correlation & 0.267 & 0.16 & 0.144 & 0.244 & 0.376 \\
Stock Synchronicity & 0.217 & 0.169 & 0.056 & 0.2 & 0.34 \\
Abs Special Items & 0.022 & 0.061 & 0 & 0.004 & 0.016 \\
Prior Restate & 0.210 & 0.407 & 0 & 0 & 0 \\
SEC Resources & 0.014 & 0.007 & 0.010 & 0.013 & 0.017 \\
\hline
\end{tabular}


Panel B: Issuance vs. Non-Issuance of Accounting Comment Letter

\begin{tabular}{|c|c|c|c|c|c|c|}
\hline \multirow[b]{2}{*}{ Variable } & \multicolumn{2}{|c|}{$\begin{array}{c}C L_{-} A c c t=1 \\
(\mathrm{~N}=6,565)\end{array}$} & \multicolumn{2}{|c|}{$\begin{array}{l}C L_{\_} A c c t=0 \\
(\mathrm{~N}=17,510)\end{array}$} & \multicolumn{2}{|c|}{$\begin{array}{c}\text { Test of Differences } \\
(p \text {-value })\end{array}$} \\
\hline & Mean & Median & Mean & Median & Mean & Median \\
\hline Comparability & -0.029 & -0.019 & -0.038 & -0.024 & 0.000 & 0.000 \\
\hline High_Comp & 0.582 & 1 & 0.469 & 0 & 0.000 & 0.000 \\
\hline Disc_Accr & 0.065 & 0.038 & 0.073 & 0.042 & 0.000 & 0.000 \\
\hline$M \& A$ & 0.210 & 0 & 0.184 & 0 & 0.000 & 0.000 \\
\hline High Volatility & 0.196 & 0 & 0.270 & 0 & 0.000 & 0.000 \\
\hline $\log (M k t$ Cap $)$ & 7.001 & 7.045 & 6.217 & 6.203 & 0.000 & 0.000 \\
\hline Firm Age & 23.480 & 19 & 21.454 & 17 & 0.000 & 0.000 \\
\hline Loss & 0.253 & 0 & 0.308 & 0 & 0.000 & 0.000 \\
\hline Bankruptcy & 4.516 & 5 & 4.490 & 4 & 0.533 & 0.540 \\
\hline Ext Financing & -0.003 & -0.016 & 0.015 & -0.009 & 0.000 & 0.000 \\
\hline Big4 & 0.823 & 1 & 0.731 & 1 & 0.000 & 0.000 \\
\hline Second Tier & 0.096 & 0 & 0.129 & 0 & 0.000 & 0.000 \\
\hline Stock Correlation & 0.297 & 0.282 & 0.255 & 0.231 & 0.000 & 0.000 \\
\hline Stock Synchronicity & 0.251 & 0.243 & 0.204 & 0.183 & 0.000 & 0.000 \\
\hline Abs Special Items & 0.023 & 0.004 & 0.022 & 0.003 & 0.485 & 0.000 \\
\hline Prior Restate & 0.218 & 0 & 0.207 & 0 & 0.056 & 0.054 \\
\hline SEC Resources & 0.015 & 0.014 & 0.014 & 0.013 & 0.000 & 0.000 \\
\hline
\end{tabular}

Panel C: High vs. Low Comparability

\begin{tabular}{|c|c|c|c|c|c|c|}
\hline \multirow[b]{2}{*}{ Variable } & \multicolumn{2}{|c|}{$\begin{array}{c}\text { High_Comp }=1 \\
(\mathrm{~N}=12,042)\end{array}$} & \multicolumn{2}{|c|}{$\begin{array}{c}\text { High_Comp }=0 \\
(\mathrm{~N}=12,033)\end{array}$} & \multicolumn{2}{|c|}{$\begin{array}{c}\text { Test of Differences } \\
\text { ( } p \text {-value })\end{array}$} \\
\hline & Mean & Median & Mean & Median & Mean & Median \\
\hline$C L \_A c c t$ & 0.317 & 0 & 0.228 & 0 & 0.000 & 0.000 \\
\hline Comparability & -0.013 & -0.013 & -0.058 & -0.042 & 0.000 & 0.000 \\
\hline Disc_Accr & 0.047 & 0.030 & 0.095 & 0.057 & 0.000 & 0.000 \\
\hline$M \& A$ & 0.232 & 0 & 0.151 & 0 & 0.000 & 0.000 \\
\hline High Volatility & 0.095 & 0 & 0.404 & 0 & 0.000 & 0.000 \\
\hline $\log ($ Mkt Cap $)$ & 7.353 & 7.385 & 5.508 & 5.407 & 0.000 & 0.000 \\
\hline Firm Age & 26.310 & 22 & 17.698 & 15 & 0.000 & 0.000 \\
\hline Loss & 0.152 & 0 & 0.434 & 0 & 0.000 & 0.000 \\
\hline Bankruptcy & 4.524 & 5 & 4.470 & 4 & 0.145 & 0.136 \\
\hline External Financing & -0.018 & -0.021 & 0.038 & -0.000 & 0.000 & 0.000 \\
\hline Big4 & 0.891 & 1 & 0.622 & 1 & 0.000 & 0.000 \\
\hline Second Tier & 0.066 & 0 & 0.174 & 0 & 0.000 & 0.000 \\
\hline Stock Correlation & 0.326 & 0.318 & 0.208 & 0.183 & 0.000 & 0.000 \\
\hline Stock Synchronicity & 0.285 & 0.282 & 0.148 & 0.102 & 0.000 & 0.000 \\
\hline Abs Special Items & 0.017 & 0.004 & 0.027 & 0.003 & 0.000 & 0.000 \\
\hline Prior Restate & 0.211 & 0 & 0.209 & 0 & 0.657 & 0.657 \\
\hline SEC Resources & 0.015 & 0.014 & 0.014 & 0.013 & 0.000 & 0.000 \\
\hline
\end{tabular}

Note: We use a t-test (the Wilcoxon rank-sum test) to test the difference in the means (medians) in panels B and C. 
TABLE 3

Correlation Table

\begin{tabular}{|c|c|c|c|c|c|c|c|c|c|c|c|c|c|c|c|c|c|c|c|c|}
\hline & & (1) & (2) & (3) & (4) & (5) & (6) & (7) & (8) & (9) & (10) & (11) & (12) & (13) & (14) & (15) & (16) & (17) & (18) & (19) \\
\hline (1) & $C L \_A c c t$ & 1.00 & & & & & & & & & & & & & & & & & & \\
\hline (2) & CL_Core & 0.71 & 1.00 & & & & & & & & & & & & & & & & & \\
\hline (3) & $C L \_3 Y r$ & 0.80 & 0.52 & 1.00 & & & & & & & & & & & & & & & & \\
\hline (4) & High_Comp & 0.10 & 0.04 & 0.19 & 1.00 & & & & & & & & & & & & & & & \\
\hline (5) & Disc_Accr & -0.04 & -0.01 & -0.09 & -0.26 & 1.00 & & & & & & & & & & & & & & \\
\hline (6) & $M \& A$ & 0.03 & -0.01 & 0.05 & 0.10 & -0.07 & 1.00 & & & & & & & & & & & & & \\
\hline (7) & High Volatility & -0.08 & -0.03 & -0.14 & -0.36 & 0.26 & -0.11 & 1.00 & & & & & & & & & & & & \\
\hline (8) & $\log ($ Mkt Cap $)$ & 0.17 & 0.07 & 0.32 & 0.45 & -0.27 & 0.19 & -0.39 & 1.00 & & & & & & & & & & & \\
\hline (9) & Firm Age & 0.06 & 0.00 & 0.10 & 0.29 & -0.17 & 0.04 & -0.24 & 0.34 & 1.00 & & & & & & & & & & \\
\hline (10) & Loss & -0.05 & -0.01 & -0.13 & -0.31 & 0.28 & -0.06 & 0.37 & -0.40 & -0.23 & 1.00 & & & & & & & & & \\
\hline (11) & Bankruptcy & 0.00 & -0.01 & -0.00 & 0.01 & 0.13 & 0.02 & 0.23 & -0.16 & -0.02 & 0.41 & 1.00 & & & & & & & & \\
\hline (12) & Ext Financing & -0.05 & -0.01 & -0.09 & -0.18 & 0.18 & -0.02 & 0.27 & -0.19 & -0.16 & 0.29 & 0.20 & 1.00 & & & & & & & \\
\hline (13) & Big4 & 0.10 & 0.05 & 0.22 & 0.31 & -0.18 & 0.10 & -0.22 & 0.54 & 0.11 & -0.16 & -0.00 & -0.10 & 1.00 & & & & & & \\
\hline (14) & Second Tier & -0.05 & -0.02 & -0.11 & -0.17 & 0.06 & -0.03 & 0.10 & -0.27 & -0.07 & 0.09 & -0.01 & 0.03 & -0.65 & 1.00 & & & & & \\
\hline (15) & Stock Corr & 0.12 & 0.02 & 0.27 & 0.37 & -0.23 & 0.13 & -0.21 & 0.56 & 0.30 & -0.20 & 0.06 & -0.14 & 0.38 & -0.19 & 1.00 & & & & \\
\hline (16) & Stock Synchr & 0.12 & 0.02 & 0.28 & 0.41 & -0.25 & 0.23 & -0.35 & 0.68 & 0.34 & -0.29 & -0.08 & -0.17 & 0.43 & -0.21 & 0.72 & 1.00 & & & \\
\hline (17) & Abs Special Items & 0.00 & 0.00 & -0.01 & -0.08 & 0.39 & 0.01 & 0.13 & -0.15 & -0.07 & 0.33 & 0.21 & 0.05 & -0.03 & 0.02 & -0.06 & -0.09 & 1.00 & & \\
\hline (18) & Prior Restate & 0.01 & 0.02 & 0.01 & 0.00 & 0.02 & -0.00 & 0.05 & -0.04 & -0.04 & 0.06 & 0.09 & -0.00 & -0.00 & 0.01 & -0.04 & -0.06 & 0.04 & 1.00 & \\
\hline (19) & SEC Resources & 0.05 & 0.06 & 0.10 & 0.04 & 0.00 & -0.14 & -0.05 & -0.11 & -0.03 & -0.05 & -0.05 & -0.10 & -0.01 & 0.01 & -0.11 & -0.11 & 0.01 & 0.01 & 1.00 \\
\hline
\end{tabular}

Note: Boldface indicates significance at the 5\% level. 
TABLE 4

Accounting-Related Comment Letters and Accounting Quality

\begin{tabular}{|c|c|c|c|}
\hline & $C L \_A c c t$ & CL_Core & $C L \_3 Y r$ \\
\hline Logit & (1) & (2) & (3) \\
\hline \multirow[t]{2}{*}{ Disc_Accr } & -0.074 & 0.052 & -0.122 \\
\hline & $(-0.37)$ & $(0.24)$ & $(-0.50)$ \\
\hline \multirow[t]{2}{*}{$M \& A$} & $0.169 * * *$ & $0.115^{* *}$ & $0.191 * * *$ \\
\hline & $(4.04)$ & $(2.24)$ & (3.07) \\
\hline \multirow[t]{2}{*}{ High Volatility } & -0.038 & 0.008 & 0.060 \\
\hline & $(-0.92)$ & $(0.16)$ & (1.04) \\
\hline \multirow[t]{2}{*}{$\log ($ Mkt Cap $)$} & $0.214 * * *$ & $0.176^{* * *}$ & $0.390 * * *$ \\
\hline & $(17.55)$ & $(11.87)$ & (17.49) \\
\hline \multirow[t]{2}{*}{ Firm Age } & -0.001 & $-0.002 *$ & -0.003 \\
\hline & $(-0.96)$ & $(-1.69)$ & $(-1.61)$ \\
\hline \multirow[t]{2}{*}{ Loss } & $0.088 * *$ & $0.192 * * *$ & 0.010 \\
\hline & $(1.97)$ & $(3.64)$ & $(0.16)$ \\
\hline \multirow[t]{2}{*}{ Bankruptcy } & $0.022 * * *$ & 0.002 & $0.039 * * *$ \\
\hline & $(3.70)$ & $(0.35)$ & $(4.02)$ \\
\hline \multirow[t]{2}{*}{ External Financing } & $-0.248 * *$ & -0.087 & -0.214 \\
\hline & $(-2.33)$ & $(-0.70)$ & $(-1.55)$ \\
\hline \multirow[t]{2}{*}{ Big4 } & -0.061 & -0.093 & -0.146 \\
\hline & $(-1.11)$ & $(-1.36)$ & $(-1.63)$ \\
\hline \multirow[t]{2}{*}{ Second Tier } & 0.023 & -0.037 & -0.069 \\
\hline & $(0.37)$ & $(-0.47)$ & $(-0.71)$ \\
\hline \multirow[t]{2}{*}{ Stock Correlation } & $0.293 * *$ & -0.101 & $0.575 * *$ \\
\hline & $(2.04)$ & $(-0.57)$ & $(2.35)$ \\
\hline \multirow[t]{2}{*}{ Stock Synchronicity } & -0.046 & -0.261 & 0.419 \\
\hline & $(-0.28)$ & $(-1.28)$ & $(1.44)$ \\
\hline \multirow[t]{2}{*}{ Abs Special Items } & $0.586 * *$ & 0.052 & $0.952 * * *$ \\
\hline & $(2.16)$ & $(0.16)$ & $(2.59)$ \\
\hline \multirow[t]{2}{*}{ Prior Restate } & $0.108 * * *$ & $0.129 * * *$ & $0.099 *$ \\
\hline & $(3.14)$ & $(3.04)$ & $(1.72)$ \\
\hline \multirow[t]{2}{*}{ Intercept } & $-2.660 * * *$ & $-2.336 * * *$ & $1.496^{* * *}$ \\
\hline & $(-23.66)$ & $(-18.07)$ & $(4.71)$ \\
\hline $\mathrm{N}$ & 24,075 & 24,075 & 14,030 \\
\hline pseudo R-sq & 0.045 & 0.037 & 0.193 \\
\hline
\end{tabular}

Note: This table presents the estimation result of equation (6). The dependent variable, $C L \_A c c t\left(C L \_C o r e\right)$, is equal to one if the company received a $10-\mathrm{K}$ comment letter in which accounting (core earnings) issues were discussed for the fiscal year $\mathrm{t}$ filing, and zero otherwise. $C L \_3 Y r$ is equal to one if the firm received a comment letter on its $10-\mathrm{K}$ filing for fiscal year $\mathrm{t}$, and zero if the firm did not receive a $10-\mathrm{K}$ comment letter for fiscal years $\mathrm{t}$, $\mathrm{t}-1$, and $\mathrm{t}-2$. Disc_Accr is the absolute value of discretionary accruals measured by the modified Jones model (Kothari et al. 2005). Other variables are defined in Appendix 1. Z-statistics are in parentheses. Year dummies and AD Office dummies are included. Continuous variables are winsorized at the $1 \%$ and $99 \%$ levels. $*, * *, * * *$ indicate significance at the $10 \%$, $5 \%$ and $1 \%$ levels (two-tailed), respectively. Standard errors are clustered at the firm level. 
TABLE 5

The SEC's Detection of Poor Quality 10-K Filings and Financial Statement Comparability

\begin{tabular}{|c|c|c|c|c|}
\hline & & $C L \_A c c t$ & CL_Core & $C L \_3 Y r$ \\
\hline Logit & Pred. & (1) & (2) & (3) \\
\hline \multirow[t]{2}{*}{ Disc_Accr x High_Comp } & + & $0.806 * *$ & $1.013 * *$ & $1.974 * * *$ \\
\hline & & (1.99) & $(2.12)$ & $(3.17)$ \\
\hline \multirow[t]{2}{*}{ Disc_Accr } & & -0.259 & -0.181 & -0.432 \\
\hline & & $(-1.14)$ & $(-0.72)$ & $(-1.62)$ \\
\hline \multirow[t]{2}{*}{ High_Comp } & & -0.017 & -0.051 & -0.087 \\
\hline & & $(-0.39)$ & $(-0.95)$ & $(-1.28)$ \\
\hline \multirow[t]{2}{*}{$M \& A$} & & $0.166^{* * *}$ & $0.113 * *$ & $0.190 * * *$ \\
\hline & & $(3.97)$ & $(2.20)$ & $(3.05)$ \\
\hline \multirow[t]{2}{*}{ High Volatility } & & -0.030 & 0.012 & 0.069 \\
\hline & & $(-0.73)$ & $(0.24)$ & (1.18) \\
\hline \multirow[t]{2}{*}{$\log ($ Mkt Cap $)$} & & $0.213 * * *$ & $0.175^{* * *}$ & $0.389 * * *$ \\
\hline & & $(17.35)$ & $(11.75)$ & $(17.38)$ \\
\hline \multirow[t]{2}{*}{ Firm Age } & & -0.001 & -0.002 & -0.003 \\
\hline & & $(-0.92)$ & $(-1.62)$ & $(-1.53)$ \\
\hline \multirow[t]{2}{*}{ Loss } & & $0.085^{*}$ & $0.185^{* * *}$ & -0.005 \\
\hline & & $(1.89)$ & $(3.45)$ & $(-0.08)$ \\
\hline \multirow[t]{2}{*}{ Bankruptcy } & & $0.022 * * *$ & 0.003 & $0.040 * * *$ \\
\hline & & $(3.67)$ & $(0.44)$ & $(4.11)$ \\
\hline \multirow[t]{2}{*}{ External Financing } & & $-0.236 * *$ & -0.071 & -0.195 \\
\hline & & $(-2.21)$ & $(-0.57)$ & $(-1.41)$ \\
\hline \multirow[t]{2}{*}{ Big4 } & & -0.069 & -0.100 & $-0.159 *$ \\
\hline & & $(-1.25)$ & $(-1.47)$ & $(-1.77)$ \\
\hline \multirow[t]{2}{*}{ Second Tier } & & 0.018 & -0.042 & -0.077 \\
\hline & & $(0.29)$ & $(-0.53)$ & $(-0.79)$ \\
\hline \multirow[t]{2}{*}{ Stock Correlation } & & $0.294 * *$ & -0.091 & $0.576^{* *}$ \\
\hline & & $(2.05)$ & $(-0.51)$ & $(2.36)$ \\
\hline \multirow[t]{2}{*}{ Stock Synchronicity } & & -0.054 & -0.264 & 0.428 \\
\hline & & $(-0.32)$ & $(-1.30)$ & $(1.47)$ \\
\hline \multirow[t]{2}{*}{ Abs Special Items } & & $0.522 *$ & -0.030 & $0.881 * *$ \\
\hline & & $(1.89)$ & $(-0.09)$ & $(2.36)$ \\
\hline \multirow[t]{2}{*}{ Prior Restate } & & $0.107 * * *$ & $0.128 * * *$ & $0.097 *$ \\
\hline & & $(3.11)$ & $(3.02)$ & (1.68) \\
\hline \multirow[t]{2}{*}{ Intercept } & & $-2.633 * * *$ & $-2.304 * * *$ & $1.543 * * *$ \\
\hline & & $(-23.31)$ & $(-17.78)$ & $(4.83)$ \\
\hline \multicolumn{2}{|l|}{$\mathrm{N}$} & 24,075 & 24,075 & 14,030 \\
\hline \multicolumn{2}{|l|}{ pseudo R-sq } & 0.046 & 0.037 & 0.193 \\
\hline \multirow[t]{2}{*}{ Mean Interaction Effect } & + & $0.153 * *$ & $0.132 * *$ & $0.369 * * *$ \\
\hline & & $(1.97)$ & $(2.07)$ & (3.07) \\
\hline
\end{tabular}


Note: This table presents the estimation result of equation (7). The dependent variable, $C L \_A c c t$ (CL_Core), is equal to one if the company received a comment letter in which accounting (core earnings) issues were discussed for the fiscal year $\mathrm{t}$ filing, and zero otherwise. $C L \_3 Y r$ is equal to one if the firm received a comment letter on its $10-\mathrm{K}$ filing for fiscal year $\mathrm{t}$, and zero if the firm did not receive a 10-K comment letter for fiscal years t, $\mathrm{t}-1$, and $\mathrm{t}-2$. High_Comp is equal to 1 if Comparability is above the annual median, and 0 otherwise. Disc_Accr is the absolute value of discretionary accruals measured by the modified Jones model (Kothari et al. 2005). Other variables are defined in Appendix 1.Z-statistics are in parentheses. Year dummies and AD Office dummies are included. Continuous variables are winsorized at the $1 \%$ and $99 \%$ levels. $*, * *, * * *$ indicate significance at the $10 \%, 5 \%$ and $1 \%$ levels (two-tailed), respectively. Standard errors are clustered at the firm level. Following the procedure in Norton et al. (2004), the mean interaction effects are provided and the mean z-statistics are in parentheses. 
TABLE 6 SEC Monitoring Constraints and Financial Statement Comparability Panel A: SEC Staffing (year $\mathrm{t}+1$ )

\begin{tabular}{|c|c|c|c|c|c|c|c|}
\hline & & \multicolumn{3}{|c|}{ Low SEC Resources year $t+1$} & \multicolumn{3}{|c|}{ High SEC Resources year $t+1$} \\
\hline & & $C L \_A c c t$ & CL_Core & $C L \_3 Y r$ & $C L \_A c c t$ & CL_Core & $C L \_3 Y r$ \\
\hline Logit & Pred. & (1) & (2) & (3) & (4) & (5) & (6) \\
\hline Disc_Accr $x$ High_Comp & + & $\begin{array}{c}1.671 * * * \\
(2.59)\end{array}$ & $\begin{array}{c}2.242 * * * \\
(2.85)\end{array}$ & $\begin{array}{c}2.941 * * * \\
(3.07)\end{array}$ & $\begin{array}{l}0.164 \\
(0.31)\end{array}$ & $\begin{array}{l}0.296 \\
(0.48)\end{array}$ & $\begin{array}{l}1.120 \dagger \\
(1.36)\end{array}$ \\
\hline Disc_Accr & & $\begin{array}{c}-0.579 * \\
(-1.87)\end{array}$ & $\begin{array}{l}-0.476 \\
(-1.41)\end{array}$ & $\begin{array}{l}-0.550 * \\
(-1.74)\end{array}$ & $\begin{array}{l}0.199 \\
(0.58)\end{array}$ & $\begin{array}{l}0.294 \\
(0.79)\end{array}$ & $\begin{array}{l}-0.160 \\
(-0.35)\end{array}$ \\
\hline High_Comp & & $\begin{array}{l}-0.077 \\
(-1.19)\end{array}$ & $\begin{array}{l}-0.099 \\
(-1.18)\end{array}$ & $\begin{array}{c}-0.202 * * \\
(-2.14)\end{array}$ & $\begin{array}{l}0.036 \\
(0.59)\end{array}$ & $\begin{array}{l}-0.014 \\
(-0.20)\end{array}$ & $\begin{array}{l}0.050 \\
(0.53)\end{array}$ \\
\hline$M \& A$ & & $\begin{array}{c}0.190 * * * \\
(3.44)\end{array}$ & $\begin{array}{c}0.137 * * \\
(1.97)\end{array}$ & $\begin{array}{c}0.147 * \\
(1.92)\end{array}$ & $\begin{array}{l}0.107 \\
(1.62)\end{array}$ & $\begin{array}{l}0.013 \\
(0.17)\end{array}$ & $\begin{array}{l}0.157 \\
(1.54)\end{array}$ \\
\hline High Volatility & & $\begin{array}{c}-0.128 * * \\
(-1.99)\end{array}$ & $\begin{array}{l}-0.044 \\
(-0.52)\end{array}$ & $\begin{array}{l}-0.063 \\
(-0.77)\end{array}$ & $\begin{array}{l}0.050 \\
(0.91)\end{array}$ & $\begin{array}{l}0.033 \\
(0.53)\end{array}$ & $\begin{array}{c}0.147 * \\
(1.75)\end{array}$ \\
\hline $\log ($ Mkt Cap $)$ & & $\begin{array}{c}0.272 * * * \\
(15.47)\end{array}$ & $\begin{array}{c}0.229 * * * \\
(10.33)\end{array}$ & $\begin{array}{c}0.407 * * * \\
(14.25)\end{array}$ & $\begin{array}{c}0.151^{* * * *} \\
(8.93)\end{array}$ & $\begin{array}{c}0.121 * * * \\
(5.97)\end{array}$ & $\begin{array}{c}0.332 * * * \\
(9.98)\end{array}$ \\
\hline Firm Age & & $\begin{array}{l}-0.001 \\
(-0.61)\end{array}$ & $\begin{array}{c}-0.005^{* *} \\
(-2.12)\end{array}$ & $\begin{array}{l}-0.001 \\
(-0.32)\end{array}$ & $\begin{array}{l}-0.001 \\
(-1.00)\end{array}$ & $\begin{array}{l}-0.001 \\
(-0.66)\end{array}$ & $\begin{array}{c}-0.008^{* * *} \\
(-2.71)\end{array}$ \\
\hline Loss & & $\begin{array}{l}0.031 \\
(0.47)\end{array}$ & $\begin{array}{l}0.076 \\
(0.90)\end{array}$ & $\begin{array}{l}-0.036 \\
(-0.45)\end{array}$ & $\begin{array}{c}0.135^{* *} \\
(2.27)\end{array}$ & $\begin{array}{c}0.258 * * * \\
(3.81)\end{array}$ & $\begin{array}{l}0.028 \\
(0.31)\end{array}$ \\
\hline Bankruptcy & & $\begin{array}{c}0.030 * * * \\
(3.40)\end{array}$ & $\begin{array}{l}0.010 \\
(0.93)\end{array}$ & $\begin{array}{c}0.036^{* * * *} \\
(2.82)\end{array}$ & $\begin{array}{c}0.016^{*} \\
(1.88)\end{array}$ & $\begin{array}{l}-0.002 \\
(-0.16)\end{array}$ & $\begin{array}{c}0.044 * * * \\
(3.01)\end{array}$ \\
\hline External Financing & & $\begin{array}{l}-0.065 \\
(-0.47)\end{array}$ & $\begin{array}{l}0.032 \\
(0.19)\end{array}$ & $\begin{array}{l}-0.062 \\
(-0.37)\end{array}$ & $\begin{array}{c}-0.356^{* *} \\
(-2.08)\end{array}$ & $\begin{array}{l}-0.102 \\
(-0.55)\end{array}$ & $\begin{array}{c}-0.413^{*} \\
(-1.80)\end{array}$ \\
\hline Big4 & & $\begin{array}{l}-0.093 \\
(-1.04)\end{array}$ & $\begin{array}{l}-0.012 \\
(-0.10)\end{array}$ & $\begin{array}{l}-0.113 \\
(-0.96)\end{array}$ & $\begin{array}{l}-0.029 \\
(-0.40)\end{array}$ & $\begin{array}{l}-0.122 \\
(-1.43)\end{array}$ & $\begin{array}{l}-0.127 \\
(-1.02)\end{array}$ \\
\hline Second Tier & & $\begin{array}{l}-0.048 \\
(-0.47)\end{array}$ & $\begin{array}{l}-0.093 \\
(-0.72)\end{array}$ & $\begin{array}{l}-0.111 \\
(-0.86)\end{array}$ & $\begin{array}{l}0.079 \\
(0.95)\end{array}$ & $\begin{array}{l}-0.003 \\
(-0.03)\end{array}$ & $\begin{array}{l}-0.021 \\
(-0.16)\end{array}$ \\
\hline Stock Correlation & & $\begin{array}{l}0.236 \\
(1.17)\end{array}$ & $\begin{array}{l}-0.248 \\
(-0.95)\end{array}$ & $\begin{array}{c}0.882 * * * \\
(2.76)\end{array}$ & $\begin{array}{l}0.284 \\
(1.39)\end{array}$ & $\begin{array}{l}0.114 \\
(0.47)\end{array}$ & $\begin{array}{l}0.500 \\
(1.41)\end{array}$ \\
\hline Stock Synchronicity & & $\begin{array}{l}-0.238 \\
(-1.03)\end{array}$ & $\begin{array}{c}-0.580^{*} \\
(-1.90)\end{array}$ & $\begin{array}{l}0.001 \\
(0.00)\end{array}$ & $\begin{array}{l}0.285 \\
(1.23)\end{array}$ & $\begin{array}{l}0.043 \\
(0.16)\end{array}$ & $\begin{array}{c}0.800 * \\
(1.90)\end{array}$ \\
\hline Abs Special Items & & $\begin{array}{c}1.146 * * * \\
(2.76)\end{array}$ & $\begin{array}{l}0.636 \\
(1.25)\end{array}$ & $\begin{array}{l}0.727 \\
(1.45)\end{array}$ & $\begin{array}{l}0.003 \\
(0.01)\end{array}$ & $\begin{array}{l}-0.563 \\
(-1.29)\end{array}$ & $\begin{array}{c}0.922^{*} \\
(1.65)\end{array}$ \\
\hline Prior Restate & & $\begin{array}{c}0.146 * * * \\
(2.68)\end{array}$ & $\begin{array}{c}0.165^{* *} \\
(2.40)\end{array}$ & $\begin{array}{c}0.152 * \\
(1.91)\end{array}$ & $\begin{array}{c}0.078 * \\
(1.74)\end{array}$ & $\begin{array}{c}0.098 * \\
(1.81)\end{array}$ & $\begin{array}{l}0.033 \\
(0.42)\end{array}$ \\
\hline Intercept & & $\begin{array}{c}-3.070 * * * \\
(-15.97)\end{array}$ & $\begin{array}{c}-3.309 * * * \\
(-14.52) \\
\end{array}$ & $\begin{array}{c}-2.408 * * * \\
(-9.60) \\
\end{array}$ & $\begin{array}{c}-2.114 * * * \\
(-14.92)\end{array}$ & $\begin{array}{c}-2.021 * * * \\
(-12.64)\end{array}$ & $\begin{array}{c}1.991 * * * \\
(5.82)\end{array}$ \\
\hline $\mathrm{N}$ & & 12,232 & 12,232 & 7,374 & 11,843 & 11,843 & 6,656 \\
\hline pseudo R-sq & & 0.069 & 0.052 & 0.176 & 0.027 & 0.017 & 0.186 \\
\hline Mean Interaction Effect & + & $\begin{array}{c}0.293^{* *} \\
(2.50)\end{array}$ & $\begin{array}{c}0.250^{* *} \\
(2.63)\end{array}$ & $\begin{array}{c}0.571 * * * \\
(2.99)\end{array}$ & $\begin{array}{l}0.034 \\
(0.31)\end{array}$ & $\begin{array}{l}0.045 \\
(0.48)\end{array}$ & $\begin{array}{c}0.203 \dagger \\
(1.35)\end{array}$ \\
\hline
\end{tabular}


Panel B: SEC Staffing (year t)

\begin{tabular}{|c|c|c|c|c|c|c|c|}
\hline & & \multicolumn{3}{|c|}{ Low SEC Resources year $t$} & \multicolumn{3}{|c|}{ High SEC Resources year $t$} \\
\hline & & $C L \_A c c t$ & CL_Core & $C L \_3 Y r$ & $C L \_A c c t$ & CL_Core & $C L \_3 Y r$ \\
\hline Logit & Pred. & (1) & $(2)$ & (3) & (4) & $(5)$ & (6) \\
\hline Disc_Accrx $x$ High_Comp & + & $\begin{array}{c}1.492 * * \\
(2.32)\end{array}$ & $\begin{array}{c}2.015 * * * \\
(2.62)\end{array}$ & $\begin{array}{c}2.706 * * * \\
(2.76)\end{array}$ & $\begin{array}{l}0.227 \\
(0.43)\end{array}$ & $\begin{array}{l}0.313 \\
(0.50)\end{array}$ & $\begin{array}{c}1.120 \dagger \\
(1.39)\end{array}$ \\
\hline Disc_Accr & & $\begin{array}{l}-0.409 \\
(-1.35)\end{array}$ & $\begin{array}{l}-0.393 \\
(-1.19)\end{array}$ & $\begin{array}{l}-0.342 \\
(-1.07)\end{array}$ & $\begin{array}{l}0.073 \\
(0.21)\end{array}$ & $\begin{array}{l}0.278 \\
(0.73)\end{array}$ & $\begin{array}{l}-0.331 \\
(-0.69)\end{array}$ \\
\hline High Comp & & $\begin{array}{l}-0.077 \\
(-1.18)\end{array}$ & $\begin{array}{l}-0.078 \\
(-0.93)\end{array}$ & $\begin{array}{c}-0.211 * * \\
(-2.22)\end{array}$ & $\begin{array}{l}0.043 \\
(0.70)\end{array}$ & $\begin{array}{l}-0.018 \\
(-0.25)\end{array}$ & $\begin{array}{l}0.058 \\
(0.62)\end{array}$ \\
\hline Controls & & Yes & Yes & Yes & Yes & Yes & Yes \\
\hline $\mathrm{N}$ & & 12,126 & 12,126 & 7,234 & 11,949 & 11,949 & 6,796 \\
\hline pseudo R-sq & & 0.066 & 0.050 & 0.202 & 0.028 & 0.017 & 0.182 \\
\hline Mean Interaction Effect & + & $\begin{array}{c}0.259 * * \\
(2.25)\end{array}$ & $\begin{array}{c}0.229 * * \\
(2.44)\end{array}$ & $\begin{array}{c}0.508 * * * \\
(2.65)\end{array}$ & $\begin{array}{l}0.047 \\
(0.43)\end{array}$ & $\begin{array}{l}0.047 \\
(0.50)\end{array}$ & $\begin{array}{c}0.205 \dagger \\
(1.38)\end{array}$ \\
\hline
\end{tabular}

Note: This table presents the estimation result of equation (7) for the subsamples partitioned by the annual median SEC Resources, which is the annual number of an AD Office's employees divided by the annual total market value (in billions) of firms covered by the office. Panels A and B respectively measure SEC Resources in years $\mathrm{t}+1$ and $\mathrm{t}$. The dependent variable, $C L \_A c c t$ (CL_Core), is equal to 1 if the company received a 10-K comment letter in which accounting (core earnings) issues were discussed for the fiscal year t filing, and 0 otherwise. $C L \_3 Y r$ is equal to one if the firm received a comment letter on its $10-\mathrm{K}$ filing for fiscal year $\mathrm{t}$, and zero if the firm did not receive a $10-\mathrm{K}$ comment letter for fiscal years t, t-1, and t-2. High_Comp is equal to 1 if Comparability is above the annual median, and 0 otherwise. Disc_Accr is the absolute value of discretionary accruals measured by the modified Jones model (Kothari et al. 2005). Other variables are defined in Appendix 1. Z-statistics are in parentheses. Year dummies and AD Office dummies are included. Continuous variables are winsorized at the $1 \%$ and $99 \%$ levels. $*$, **, $* * *$, and $\dagger$ indicate significance at the 10\%, 5\%, 1\% (two-tailed), and 10\% (one-tailed if a predicted sign is made) levels, respectively. Standard errors are clustered at the firm level. Following the procedure in Norton et al. (2004), the mean interaction effects are provided and the mean z-statistics are in parentheses. 
TABLE 7

Filing Formats: XBRL

\begin{tabular}{|c|c|c|c|c|c|}
\hline & & \multicolumn{2}{|c|}{ No XBRL Tagging } & \multicolumn{2}{|c|}{ XBRL Tagging } \\
\hline & & $C L \_A c c t$ & CL_Core & $C L \_A c c t$ & CL_Core \\
\hline Logit & Pred. & (1) & (2) & (3) & (4) \\
\hline Disc_Accr $x$ High_Comp & + & $\begin{array}{c}1.640 * * \\
(2.09)\end{array}$ & $\begin{array}{c}2.736 * * * \\
(3.02)\end{array}$ & $\begin{array}{l}1.003 \\
(0.90)\end{array}$ & $\begin{array}{l}1.544 \\
(1.14)\end{array}$ \\
\hline Disc_Accr & & $\begin{array}{l}-0.287 \\
(-0.72)\end{array}$ & $\begin{array}{l}-0.371 \\
(-0.84)\end{array}$ & $\begin{array}{l}-0.412 \\
(-0.56)\end{array}$ & $\begin{array}{l}-1.220 \\
(-1.37)\end{array}$ \\
\hline High_Comp & & $\begin{array}{c}-0.176^{*} \\
(-1.69)\end{array}$ & $\begin{array}{c}-0.470 * * * \\
(-3.71)\end{array}$ & $\begin{array}{l}-0.043 \\
(-0.38)\end{array}$ & $\begin{array}{l}-0.049 \\
(-0.35)\end{array}$ \\
\hline$M \& A$ & & $\begin{array}{l}0.070 \\
(0.65)\end{array}$ & $\begin{array}{l}-0.017 \\
(-0.13)\end{array}$ & $\begin{array}{c}0.211 * * \\
(2.50)\end{array}$ & $\begin{array}{c}0.168 * \\
(1.67)\end{array}$ \\
\hline High Volatility & & $\begin{array}{l}0.130 \\
(1.51)\end{array}$ & $\begin{array}{l}0.069 \\
(0.65)\end{array}$ & $\begin{array}{l}-0.122 \\
(-1.03)\end{array}$ & $\begin{array}{l}-0.006 \\
(-0.04)\end{array}$ \\
\hline $\log ($ Mkt Cap $)$ & & $\begin{array}{c}0.181 * * * \\
(5.53)\end{array}$ & $\begin{array}{c}0.205 * * * \\
(5.18)\end{array}$ & $\begin{array}{c}0.325 * * * \\
(9.91)\end{array}$ & $\begin{array}{c}0.176 * * * \\
(4.63)\end{array}$ \\
\hline Firm Age & & $\begin{array}{l}-0.003 \\
(-1.24)\end{array}$ & $\begin{array}{c}-0.006^{*} \\
(-1.80)\end{array}$ & $\begin{array}{l}-0.004 \\
(-1.44)\end{array}$ & $\begin{array}{l}-0.001 \\
(-0.45)\end{array}$ \\
\hline Loss & & $\begin{array}{l}-0.029 \\
(-0.31)\end{array}$ & $\begin{array}{l}-0.036 \\
(-0.32)\end{array}$ & $\begin{array}{l}0.107 \\
(0.90)\end{array}$ & $\begin{array}{l}0.235 \\
(1.57)\end{array}$ \\
\hline Bankruptcy & & $\begin{array}{c}0.030 * * \\
(2.14)\end{array}$ & $\begin{array}{l}0.021 \\
(1.23)\end{array}$ & $\begin{array}{l}0.013 \\
(0.79)\end{array}$ & $\begin{array}{l}-0.025 \\
(-1.28)\end{array}$ \\
\hline External Financing & & $\begin{array}{c}-0.620 * * \\
(-2.41)\end{array}$ & $\begin{array}{l}-0.364 \\
(-1.23)\end{array}$ & $\begin{array}{l}-0.224 \\
(-0.86)\end{array}$ & $\begin{array}{l}0.077 \\
(0.25)\end{array}$ \\
\hline Big4 & & $\begin{array}{c}-0.225^{*} \\
(-1.88)\end{array}$ & $\begin{array}{l}-0.169 \\
(-1.17)\end{array}$ & $\begin{array}{l}-0.032 \\
(-0.19)\end{array}$ & $\begin{array}{l}0.055 \\
(0.25)\end{array}$ \\
\hline Second Tier & & $\begin{array}{l}0.025 \\
(0.20)\end{array}$ & $\begin{array}{l}-0.075 \\
(-0.49)\end{array}$ & $\begin{array}{l}-0.056 \\
(-0.29)\end{array}$ & $\begin{array}{l}-0.054 \\
(-0.22)\end{array}$ \\
\hline Stock Correlation & & $\begin{array}{l}0.243 \\
(0.74)\end{array}$ & $\begin{array}{l}0.180 \\
(0.43)\end{array}$ & $\begin{array}{l}0.315 \\
(0.86)\end{array}$ & $\begin{array}{l}-0.091 \\
(-0.20)\end{array}$ \\
\hline Stock Synchronicity & & $\begin{array}{l}0.535 \\
(1.38)\end{array}$ & $\begin{array}{l}-0.276 \\
(-0.57)\end{array}$ & $\begin{array}{l}0.106 \\
(0.26)\end{array}$ & $\begin{array}{l}0.425 \\
(0.91)\end{array}$ \\
\hline Abs Special Items & & $\begin{array}{l}0.019 \\
(0.04)\end{array}$ & $\begin{array}{l}-0.498 \\
(-0.91)\end{array}$ & $\begin{array}{l}1.565 \\
(1.51)\end{array}$ & $\begin{array}{l}0.399 \\
(0.28)\end{array}$ \\
\hline Prior Restate & & $\begin{array}{c}0.146^{*} \\
(1.80)\end{array}$ & $\begin{array}{l}0.163 \\
(1.63)\end{array}$ & $\begin{array}{l}0.145 \\
(1.41)\end{array}$ & $\begin{array}{l}0.020 \\
(0.16)\end{array}$ \\
\hline Intercept & & $\begin{array}{c}-1.919 * * * \\
(-8.34)\end{array}$ & $\begin{array}{c}-2.358 * * * \\
(-8.63) \\
\end{array}$ & $\begin{array}{c}-3.231 * * * \\
(-11.61)\end{array}$ & $\begin{array}{c}-2.643 * * * \\
(-8.19)\end{array}$ \\
\hline $\begin{array}{l}\mathrm{N} \\
\text { pseudo R-sq }\end{array}$ & & $\begin{array}{l}4,112 \\
0.050\end{array}$ & $\begin{array}{l}4,112 \\
0.043\end{array}$ & $\begin{array}{l}3,877 \\
0.085\end{array}$ & $\begin{array}{l}3,863 \\
0.058\end{array}$ \\
\hline Mean Interaction Effect & + & $\begin{array}{c}0.311 * * \\
(2.03)\end{array}$ & $\begin{array}{c}0.347 * * * \\
(2.63)\end{array}$ & $\begin{array}{l}0.199 \\
(0.90)\end{array}$ & $\begin{array}{l}0.200 \\
(1.09)\end{array}$ \\
\hline
\end{tabular}


Note: This table presents the estimation result of equation (7) for the subsamples of firms filing non-XBRL 10-K reports vs. those filing XBRL 10-K reports for years 2008-2012, following Bhattacharya et al. (2018). The dependent variable, $C L \_A c c t$ (CL_Core), is equal to one if the company received a $10-\mathrm{K}$ comment letter in which accounting (core earnings) issues were discussed for the fiscal year $\mathrm{t}$ filing, and zero otherwise. $C L \_3 \mathrm{Yr}$ is equal to one if the firm received a comment letter on its $10-\mathrm{K}$ filing for fiscal year $\mathrm{t}$, and zero if the firm did not receive a $10-\mathrm{K}$ comment letter for fiscal years t, t-1, and t-2. High_Comp is equal to one if Comparability is above the annual median, and zero otherwise. Disc_Accr is the absolute value of discretionary accruals measured by the modified Jones model (Kothari et al. 2005). Other variables are defined in Appendix 1. Z-statistics are in parentheses. Year dummies and AD Office dummies are included. Continuous variables are winsorized at the $1 \%$ and $99 \%$ levels. *,**, *** indicate significance at the $10 \%, 5 \%$ and $1 \%$ levels (two-tailed), respectively. Standard errors are clustered at the firm level. Following the procedure in Norton et al. (2004), the mean interaction effects are provided and the mean z-statistics are in parentheses. 
TABLE 8

Economic Comparability vs. Financial Statement Comparability

\begin{tabular}{|c|c|c|c|c|c|c|c|}
\hline & & CL_Acct & CL_Core & $C L \_3 Y r$ & $C L \_A c c t$ & CL_Core & $C L \_3 Y r$ \\
\hline Logit & Pred. & (1) & (2) & (3) & (4) & (5) & (6) \\
\hline \multirow[t]{2}{*}{ Disc Accr x High_Econ_Comp } & & 0.542 & 0.355 & $1.625 * * *$ & 0.088 & -0.468 & 0.824 \\
\hline & & $(1.37)$ & $(0.75)$ & $(2.79)$ & $(0.17)$ & $(-0.76)$ & $(1.19)$ \\
\hline \multirow[t]{2}{*}{ Disc_Accr $x$ High Comp } & + & & & & $0.767 \dagger$ & $1.328 * *$ & $1.494 * *$ \\
\hline & & & & & $(1.44)$ & $(2.16)$ & $(2.03)$ \\
\hline \multirow[t]{2}{*}{ Disc_Accr } & & -0.180 & -0.002 & -0.403 & -0.250 & -0.119 & $-0.492 *$ \\
\hline & & $(-0.81)$ & $(-0.01)$ & $(-1.51)$ & $(-1.09)$ & $(-0.47)$ & $(-1.81)$ \\
\hline \multirow[t]{2}{*}{ High_Econ_Comp } & & 0.035 & 0.047 & -0.038 & 0.063 & $0.111 *$ & 0.013 \\
\hline & & $(0.82)$ & $(0.93)$ & $(-0.59)$ & $(1.25)$ & $(1.82)$ & $(0.18)$ \\
\hline \multirow[t]{2}{*}{ High_Comp } & & & & & -0.045 & $-0.108^{*}$ & -0.084 \\
\hline & & & & & $(-0.85)$ & $(-1.68)$ & $(-1.12)$ \\
\hline Controls & & Yes & Yes & Yes & Yes & Yes & Yes \\
\hline $\mathrm{N}$ & & 24,075 & 24,075 & 14,030 & 24,075 & 24,075 & 14,030 \\
\hline pseudo R-sq & & 0.046 & 0.037 & 0.193 & 0.046 & 0.037 & 0.194 \\
\hline \multicolumn{8}{|l|}{ Mean Interaction Effect } \\
\hline \multirow[t]{2}{*}{ Disc Accr $x$ High_Econ_Comp } & & 0.103 & 0.047 & $0.304 * * *$ & 0.016 & -0.062 & 0.154 \\
\hline & & $(1.36)$ & $(0.755)$ & $(2.72)$ & $(0.15)$ & $(-0.77)$ & $(1.18)$ \\
\hline \multirow[t]{2}{*}{ Disc_Accr $x$ High Comp } & + & & & & $0.145 \dagger$ & $0.173 * *$ & $0.278 * *$ \\
\hline & & & & & $(1.43)$ & $(2.10)$ & $(2.00)$ \\
\hline
\end{tabular}

Note: The dependent variable, $C L \_A c c t$ (CL_Core), is equal to one if the company received a 10-K comment letter in which accounting (core earnings) issues were discussed for the fiscal year t filing, and zero otherwise. $C L \_3 Y r$ is equal to one if the firm received a comment letter on its $10-\mathrm{K}$ filing for fiscal year t, and zero if the firm did not receive a 10-K comment letter for fiscal years t, t-1, and t-2. High_Comp is equal to one if Comparability is above the annual median, and zero otherwise. High_Econ_Comp is equal to one if Econ_Comparability is above the annual median, and zero otherwise. Disc_Accr is the absolute value of discretionary accruals measured by the modified Jones model (Kothari et al. 2005). Other variables are defined in Appendix 1. Z-statistics are in parentheses. Year dummies and AD Office dummies are included. Continuous variables are winsorized at the $1 \%$ and $99 \%$ levels. *, **, ***, and $\dagger$ indicate significance at the $10 \%$, $5 \%, 1 \%$ (two-tailed), and 10\% (one-tailed if a predicted sign is made) levels, respectively. Standard errors are clustered at the firm level. Following the procedure in Norton et al. (2004), the mean interaction effects are provided and the mean $\mathrm{z}$-statistics are in parentheses. 
TABLE 9

Difference-in-Differences Test: The Elimination of Reconciliation Requirement

\begin{tabular}{|c|c|c|c|}
\hline & & CL Acct & CL Core \\
\hline Logit & Pred. & (1) & (2) \\
\hline \multirow[t]{2}{*}{ Disc Accr $x$ IFRS x Post } & - & -0.310 & $-2.311 *$ \\
\hline & & $(-0.43)$ & $(-1.68)$ \\
\hline \multirow[t]{2}{*}{ Disc Accr x Post } & & -0.222 & -0.297 \\
\hline & & $(-0.38)$ & $(-0.48)$ \\
\hline \multirow[t]{2}{*}{ Disc Accr $x$ IFRS } & & -0.024 & 0.319 \\
\hline & & $(-0.04)$ & $(0.55)$ \\
\hline \multirow[t]{2}{*}{ IFRS $x$ Post } & & -0.951 & -0.931 \\
\hline & & $(-1.23)$ & $(-1.12)$ \\
\hline \multirow[t]{2}{*}{ Disc Accr } & & 0.380 & 0.405 \\
\hline & & $(0.71)$ & $(0.75)$ \\
\hline \multirow[t]{2}{*}{ Post } & & 0.383 & 0.757 \\
\hline & & $(0.85)$ & $(1.53)$ \\
\hline \multirow[t]{2}{*}{$\operatorname{IFRS}$} & & 0.563 & 0.783 \\
\hline & & $(0.81)$ & $(0.98)$ \\
\hline Controls & & Yes & Yes \\
\hline $\mathrm{N}$ & & 325 & 317 \\
\hline pseudo R-sq & & 0.135 & 0.155 \\
\hline
\end{tabular}

Note: This table estimates the effect of the 2007 elimination of the reconciliation requirement for cross-listed foreign firms following IFRS (20F filers). The dependent variable, $C L \_A c c t$ (CL_Core), is equal to 1 if the cross-listed foreign company received a 20-F comment letter in which accounting (core earnings) issues were discussed for the fiscal year $\mathrm{t}$ filing, and 0 otherwise. Following Kim et al. (2012), IFRS is equal to one if the cross-listed firms prepares its financial statements under IFRS, and zero otherwise. Post is equal to one if the firm-year observation is in 2007, and zero if it is in 2006. Disc_Accr is the absolute value of discretionary accruals measured by the modified Jones model (Kothari et al. 2005). Other variables are defined in Appendix 1. Z-statistics are in parentheses. Year dummies, AD Office dummies, and country dummies are included. Continuous variables are winsorized at the $1 \%$ and $99 \%$ levels. *, **, $* * *$ indicate significance at the $10 \%, 5 \%$ and $1 \%$ levels (two-tailed), respectively. Standard errors are clustered at the firm level. 
TABLE 10

Revenue Comparability \& Revenue-Related Comment Letters

\begin{tabular}{|c|c|c|c|c|c|c|c|}
\hline \multirow[b]{2}{*}{ Logit } & \multirow[b]{2}{*}{ Pred. } & \multicolumn{3}{|c|}{ CL_Revenue } & \multicolumn{3}{|c|}{ CL_Non_Revenue } \\
\hline & & (1) & (2) & (3) & (4) & $(5)$ & (6) \\
\hline Disc_Rev x High_Rev_Comp & + & $\begin{array}{c}3.273 * * * \\
(2.84)\end{array}$ & & & $\begin{array}{l}-0.182 \\
(-0.14)\end{array}$ & & \\
\hline$A b n \_\Delta A R x$ High_Rev_Comp & + & & $\begin{array}{c}2.473 * * \\
(2.32)\end{array}$ & & & $\begin{array}{l}-1.616 \\
(-1.43)\end{array}$ & \\
\hline$A b n \_\Delta D e f x$ High_Rev_Comp & + & & & $\begin{array}{c}4.949 * * * \\
(2.72)\end{array}$ & & & $\begin{array}{l}0.871 \\
(0.38)\end{array}$ \\
\hline Disc_Rev & & $\begin{array}{l}-0.717 \\
(-1.09)\end{array}$ & & & $\begin{array}{l}0.021 \\
(0.03)\end{array}$ & & \\
\hline$A b n \_\Delta A R$ & & & $\begin{array}{l}-0.549 \\
(-0.93)\end{array}$ & & & $\begin{array}{l}0.139 \\
(0.20)\end{array}$ & \\
\hline$A b n \_\Delta D e f$ & & & & $\begin{array}{l}-0.090 \\
(-0.11)\end{array}$ & & & $\begin{array}{l}-0.055 \\
(-0.10)\end{array}$ \\
\hline High_Rev_Comp & & $\begin{array}{l}-0.020 \\
(-0.37)\end{array}$ & $\begin{array}{l}-0.014 \\
(-0.27)\end{array}$ & $\begin{array}{l}-0.013 \\
(-0.23)\end{array}$ & $\begin{array}{c}0.129 * * \\
(2.27)\end{array}$ & $\begin{array}{c}0.128 * * \\
(2.26)\end{array}$ & $\begin{array}{c}0.150 * * * \\
(2.64)\end{array}$ \\
\hline Controls & & Yes & Yes & Yes & Yes & Yes & Yes \\
\hline $\mathrm{N}$ & & 22,965 & 22,965 & 21,420 & 22,965 & 22,965 & 21,420 \\
\hline pseudo R-sq & & 0.038 & 0.038 & 0.040 & 0.043 & 0.043 & 0.045 \\
\hline Mean Interaction Effect & + & $\begin{array}{c}0.250 * * * \\
(2.67)\end{array}$ & $\begin{array}{c}0.189 * * \\
(2.22)\end{array}$ & $\begin{array}{c}0.382 * * \\
(2.57)\end{array}$ & $\begin{array}{l}-0.013 \\
(-0.15)\end{array}$ & $\begin{array}{l}-0.115 \\
(-1.44)\end{array}$ & $\begin{array}{l}0.062 \\
(0.38)\end{array}$ \\
\hline
\end{tabular}

Note: This table examines the effect of cross-firm comparability in revenue recognition on the SEC's review process. The dependent variable, $C L \_$Revenue, is equal to one if the firm received a comment letter with topics related to revenue (i.e., Audit Analytics topic key is 212=Revenue recognition (incl deferred revenue) issues), and zero otherwise. CL_Non_Revenue is equal to one if the firm received a comment letter which did not relate to revenue recognition, and zero otherwise. High_Rev_Comp is equal to one if cross-firm comparability in revenue recognition, as measured by DKV's algorithm based on the revenue-expenses relation, is above the median, and zero otherwise. Disc_Rev (discretionary revenues) is measured following Stubben (2010). Abn_ $\Delta A R$ (abnormal changes in gross account receivable) and $A b n \_\Delta D e f$ (abnormal changes in deferred revenue) is measured following Caylor (2010). Other variables are defined in Appendix 1. Z-statistics are in parentheses. Year dummies and AD Office dummies are included. Continuous variables are winsorized at the $1 \%$ and $99 \%$ levels. $* * *, * * *$ indicate significance at the $10 \%$, $5 \%$ and $1 \%$ levels (two-tailed), respectively. Standard errors are clustered at the firm level. Following the procedure in Norton et al. (2004), the mean interaction effects are provided and the mean z-statistics are in parentheses. 
TABLE 11

Input-Based Measures of Comparability

\begin{tabular}{|c|c|c|c|c|c|c|c|c|c|c|}
\hline & & CL_Acct & CL_Core & $C L \_3 Y r$ & CL_Acct & CL_Core & $C L \_3 Y r$ & CL_Acct & CL_Core & $C L \_3 Y r$ \\
\hline Logit & Pred. & (1) & (2) & (3) & (4) & (5) & (6) & (7) & (8) & (9) \\
\hline Disc Accr $x$ High_Input_Comp & + & $\begin{array}{c}0.654 \dagger \\
(1.54)\end{array}$ & $\begin{array}{l}-0.096 \\
(-0.20)\end{array}$ & $\begin{array}{c}0.835 \dagger \\
(1.54)\end{array}$ & & & & $\begin{array}{c}0.635 \dagger \\
(1.46)\end{array}$ & $\begin{array}{l}-0.177 \\
(-0.37)\end{array}$ & $\begin{array}{c}0.779 \dagger \\
(1.43)\end{array}$ \\
\hline Disc_Accr $x$ High_Input_Econ_Comp & & & & & $\begin{array}{l}0.271 \\
(0.66)\end{array}$ & $\begin{array}{l}0.496 \\
(1.06)\end{array}$ & $\begin{array}{l}0.601 \\
(1.15)\end{array}$ & $\begin{array}{l}0.149 \\
(0.36)\end{array}$ & $\begin{array}{l}0.512 \\
(1.09)\end{array}$ & $\begin{array}{l}0.473 \\
(0.90)\end{array}$ \\
\hline Disc_Accr & & $\begin{array}{l}-0.339 \\
(-1.07)\end{array}$ & $\begin{array}{l}0.037 \\
(0.11)\end{array}$ & $\begin{array}{l}-0.642 \\
(-1.52)\end{array}$ & $\begin{array}{l}-0.136 \\
(-0.41)\end{array}$ & $\begin{array}{l}-0.289 \\
(-0.76)\end{array}$ & $\begin{array}{l}-0.497 \\
(-1.23)\end{array}$ & $\begin{array}{l}-0.412 \\
(-1.12)\end{array}$ & $\begin{array}{l}-0.207 \\
(-0.49)\end{array}$ & $\begin{array}{c}-0.866^{*} \\
(-1.78)\end{array}$ \\
\hline High_Input_Comp & & $\begin{array}{l}-0.017 \\
(-0.33)\end{array}$ & $\begin{array}{l}0.090 \\
(1.50)\end{array}$ & $\begin{array}{c}0.139^{*} \\
(1.76)\end{array}$ & & & & $\begin{array}{l}-0.012 \\
(-0.24)\end{array}$ & $\begin{array}{l}0.098 \\
(1.64)\end{array}$ & $\begin{array}{c}0.149^{*} \\
(1.88)\end{array}$ \\
\hline High_Input_Econ_Comp & & & & & $\begin{array}{l}-0.062 \\
(-1.30)\end{array}$ & $\begin{array}{l}-0.076 \\
(-1.31)\end{array}$ & $\begin{array}{l}-0.117 \\
(-1.47)\end{array}$ & $\begin{array}{l}-0.057 \\
(-1.18)\end{array}$ & $\begin{array}{l}-0.083 \\
(-1.42)\end{array}$ & $\begin{array}{l}-0.124 \\
(-1.55)\end{array}$ \\
\hline Controls & & Yes & Yes & Yes & Yes & Yes & Yes & Yes & Yes & Yes \\
\hline $\mathrm{N}$ & & 13,746 & 13,746 & 7,914 & 13,746 & 13,746 & 7,914 & 13,746 & 13,746 & 7,914 \\
\hline pseudo R-sq & & 0.035 & 0.023 & 0.187 & 0.035 & 0.023 & 0.186 & 0.035 & 0.023 & 0.187 \\
\hline \multicolumn{11}{|l|}{ Mean Interaction Effect } \\
\hline Disc Accr $x$ High_Input_Comp & + & $\begin{array}{c}0.132 \dagger \\
(1.54)\end{array}$ & $\begin{array}{l}-0.014 \\
(-0.20)\end{array}$ & $\begin{array}{c}0.151 \dagger \\
(1.54)\end{array}$ & & & & $\begin{array}{c}0.128 \dagger \\
(1.45)\end{array}$ & $\begin{array}{l}-0.028 \\
(-0.40)\end{array}$ & $\begin{array}{c}0.142 \dagger \\
(1.45)\end{array}$ \\
\hline Disc_Accr $x$ High_Input_Econ_Comp & & & & & $\begin{array}{l}0.055 \\
(0.66)\end{array}$ & $\begin{array}{l}0.073 \\
(1.06)\end{array}$ & $\begin{array}{l}0.108 \\
(1.13)\end{array}$ & $\begin{array}{l}0.031 \\
(0.37)\end{array}$ & $\begin{array}{l}0.075 \\
(1.08)\end{array}$ & $\begin{array}{l}0.083 \\
(0.87)\end{array}$ \\
\hline
\end{tabular}

Note: The dependent variable, $C L \_$Acct (CL_Core), is equal to one if the company received a 10-K comment letter in which accounting (core earnings) issues were discussed for the fiscal year $\mathrm{t}$ filing, and zero otherwise. $C L \_3 Y r$ is equal to one if the firm received a comment letter on its $10-\mathrm{K}$ filing for fiscal year $\mathrm{t}$, and zero if the firm did not receive a 10-K comment letter for fiscal years t, $\mathrm{t}-1$, and $\mathrm{t}-2$. High_Input_Comp (High_Input_Econ_Comp) is equal to one if the input-based accounting (economic) comparability, based on textual similarities in the accounting policy disclosure (business description) found in 10-K reports, as compared to industry peers (Peterson et al. 2015), is greater than the annual median, and zero otherwise. Disc_Accr is the absolute value of discretionary accruals measured by the modified Jones model (Kothari et al. 2005). Other variables are defined in Appendix 1. Z-statistics are in parentheses. Year dummies and AD Office dummies are included. Continuous variables are winsorized at the $1 \%$ and $99 \%$ levels. *, **, ***, and $\dagger$ indicate significance at the 10\%, 5\%, 1\% (two-tailed), and $10 \%$ (one-tailed if a predicted sign is made) levels, respectively. Standard errors are clustered at the firm level. Following the procedure in Norton et al. (2004), the mean interaction effect is provided and the mean z-statistics are in parentheses. 
TABLE 12

Comment Letters Leading to Restatements

\begin{tabular}{|c|c|c|c|}
\hline & & CL_Acct_Restatement & CL_Core_Restatement \\
\hline Logit & Pred. & (1) & (2) \\
\hline \multirow[t]{2}{*}{ High_Comp } & + & $0.383 * *$ & $0.365^{*}$ \\
\hline & & $(2.01)$ & (1.69) \\
\hline \multirow[t]{2}{*}{$M \& A$} & & 0.100 & 0.254 \\
\hline & & $(0.45)$ & $(0.99)$ \\
\hline \multirow[t]{2}{*}{ High Volatility } & & $0.395 * *$ & $0.483 * *$ \\
\hline & & (1.99) & $(2.19)$ \\
\hline \multirow[t]{2}{*}{$\log (M k t$ Cap $)$} & & $-0.160 * * *$ & $-0.195 * * *$ \\
\hline & & $(-2.74)$ & $(-2.79)$ \\
\hline \multirow[t]{2}{*}{ Firm Age } & & $-0.013 * *$ & -0.011 \\
\hline & & $(-2.16)$ & $(-1.56)$ \\
\hline \multirow[t]{2}{*}{ Loss } & & 0.075 & 0.011 \\
\hline & & $(0.39)$ & $(0.05)$ \\
\hline \multirow[t]{2}{*}{ Bankruptcy } & & 0.050 & 0.026 \\
\hline & & $(1.54)$ & $(0.70)$ \\
\hline \multirow[t]{2}{*}{ External Financing } & & -0.660 & -0.744 \\
\hline & & $(-1.41)$ & $(-1.39)$ \\
\hline \multirow[t]{2}{*}{ Big4 } & & -0.226 & 0.024 \\
\hline & & $(-0.86)$ & $(0.09)$ \\
\hline \multirow[t]{2}{*}{ Second Tier } & & -0.558 & -0.387 \\
\hline & & $(-1.62)$ & $(-1.02)$ \\
\hline \multirow[t]{2}{*}{ Stock Correlation } & & $-1.654 * *$ & $-1.593 *$ \\
\hline & & $(-2.22)$ & $(-1.78)$ \\
\hline \multirow[t]{2}{*}{ Stock Synchronicity } & & $2.332 * * *$ & 1.619 \\
\hline & & $(2.73)$ & $(1.54)$ \\
\hline \multirow[t]{2}{*}{ Abs Special Items } & & -0.117 & 0.384 \\
\hline & & $(-0.08)$ & $(0.22)$ \\
\hline \multirow[t]{2}{*}{ Num Topics } & & 0.203 & 0.031 \\
\hline & & $(1.14)$ & $(0.15)$ \\
\hline \multirow[t]{2}{*}{ Filings } & & $0.247 * * *$ & $0.237 * * *$ \\
\hline & & $(7.54)$ & $(6.18)$ \\
\hline \multirow[t]{2}{*}{ Prior Restate } & & -0.021 & 0.007 \\
\hline & & $(-0.46)$ & $(0.14)$ \\
\hline \multirow[t]{2}{*}{ Intercept } & & $-15.551 * * *$ & $-15.802 * * *$ \\
\hline & & $(-25.24)$ & $(-21.84)$ \\
\hline $\mathrm{N}$ & & 6,567 & 3,814 \\
\hline pseudo R-sq & & 0.160 & 0.153 \\
\hline
\end{tabular}

Note: This table uses a logit model to regress CL_Acct_Restatement (column (1)) and CL_Core_Restatement (column (2)) on High_Comp and the control variables for the accounting-related comment letter sample (CL_ACCT=1) and the core earnings-related comment letter sample (CL_Core=1), respectively. CL_Acct_Restatement (CL_Core_Restatement) is a dummy variable that equals one if the accounting-related (core earnings-related) 
comment letter directly resulted in a restatement and zero otherwise. Other variables are defined in Appendix 1. Zstatistics are in parentheses. Year dummies and AD Office dummies are included. Continuous variables are winsorized at the $1 \%$ and $99 \%$ levels. $*, * *, * * *$ indicate significance at the $10 \%, 5 \%$, and $1 \%$ (two-tailed) levels, respectively. Standard errors are clustered at the firm level. For each column, if an industry or year dummy is perfectly correlated with the dependent variable, that dummy variable is dropped from the regression. 
TABLE 13

Non-Accounting Comment Letters

\begin{tabular}{lcc}
\hline & $C L \_N o n \_A c c t$ & $C L \_N o n \_A c c t$ \\
\hline Logit & $(1)$ & $(2)$ \\
\hline Disc_Accr x High_Comp & & -0.891 \\
& & $(-1.19)$ \\
Disc_Accr & -0.001 & 0.115 \\
& $(-0.00)$ & $(0.28)$ \\
High_Comp & & $-0.153^{* *}$ \\
& & $(-1.96)$ \\
Controls & Yes & Yes \\
\hline N & 24,075 & 24,075 \\
pseudo R-sq & 0.058 & 0.059 \\
\hline Mean Interaction Effect & & -0.050 \\
& & $(-1.15)$ \\
\hline
\end{tabular}

Note: This table presents the estimation result of equations (6) and (7) using the dependent variable, $C L \_N o n \_A c c t$, which is equal to one if the company received a comment letter relating to non-accounting topics only for the fiscal year t filing, and zero otherwise. High_Comp is equal to one if Comparability is above the annual median, and zero otherwise. Disc_Accr is the absolute value of discretionary accruals measured by the modified Jones model (Kothari et al. 2005). Other variables are defined in Appendix 1. Z-statistics are in parentheses. Year dummies and AD Office dummies are included. Continuous variables are winsorized at the $1 \%$ and $99 \%$ levels. $*$, **, *** indicate significance at the $10 \%, 5 \%$ and $1 \%$ levels (two-tailed), respectively. Standard errors are clustered at the firm level. Following the procedure in Norton et al. (2004), the mean interaction effects are provided and the mean z-statistics are in parentheses. 
TABLE A2-1

Robustness of the Results to the Measurement of Accounting Quality (Replication of Table 4)

Panel A: Alternative Discretionary Accruals Models

\begin{tabular}{|c|c|c|c|c|c|c|c|c|c|}
\hline & \multicolumn{3}{|c|}{ Jones Model } & \multicolumn{3}{|c|}{ Jones Model - ROA } & \multicolumn{3}{|c|}{ Modified Jones - ROA } \\
\hline & $C L \_A c c t$ & CL_Core & $C L \_3 Y r$ & $C L \_A c c t$ & CL_Core & $C L \_3 Y r$ & CL_Acct & CL_Core & $C L \_3 Y r$ \\
\hline Logit & (1) & (2) & (3) & (4) & (5) & (6) & (7) & (8) & (9) \\
\hline \multirow[t]{2}{*}{ Poor Accounting Quality } & -0.179 & -0.116 & -0.058 & -0.113 & 0.058 & -0.183 & -0.132 & 0.072 & -0.226 \\
\hline & $(-1.56)$ & $(-1.02)$ & $(-0.57)$ & $(-0.48)$ & $(0.22)$ & $(-0.62)$ & $(-0.57)$ & $(0.27)$ & $(-0.76)$ \\
\hline Controls & Yes & Yes & Yes & Yes & Yes & Yes & Yes & Yes & Yes \\
\hline $\mathrm{N}$ & 24,075 & 24,075 & 14,030 & 24,075 & 24,075 & 14,030 & 24,075 & 24,075 & 14,030 \\
\hline pseudo R-sq & 0.045 & 0.037 & 0.193 & 0.045 & 0.037 & 0.193 & 0.045 & 0.037 & 0.193 \\
\hline
\end{tabular}

Panel B: Alternative Accounting Quality Proxies

\begin{tabular}{|c|c|c|c|c|c|c|c|c|c|}
\hline & \multicolumn{3}{|c|}{$\operatorname{Std}(R O A)$} & \multicolumn{3}{|c|}{ Accruals Quality } & \multicolumn{3}{|c|}{ Unexpected Audit Fees } \\
\hline & $C L \_A c c t$ & CL_Core & $C L \_3 Y r$ & $C L \_A c c t$ & CL_Core & $C L \_3 Y r$ & $C L \_A c c t$ & CL_Core & $C L \_3 Y r$ \\
\hline Logit & (1) & (2) & (3) & (4) & (5) & (6) & (7) & (8) & (9) \\
\hline Poor Accounting Quality & $\begin{array}{c}-1.428 * * * \\
(-3.00)\end{array}$ & $\begin{array}{c}-1.323^{* *} \\
(-2.38)\end{array}$ & $\begin{array}{c}-1.334 * \\
(-1.94)\end{array}$ & $\begin{array}{l}0.116 \\
(0.16)\end{array}$ & $\begin{array}{c}1.850 * * \\
(2.16)\end{array}$ & $\begin{array}{l}0.242 \\
(0.20)\end{array}$ & $\begin{array}{l}0.029 \\
(0.85)\end{array}$ & $\begin{array}{l}0.013 \\
(0.33)\end{array}$ & $\begin{array}{l}0.070 \\
(1.17)\end{array}$ \\
\hline Controls & Yes & Yes & Yes & Yes & Yes & Yes & Yes & Yes & Yes \\
\hline $\mathrm{N}$ & 24,075 & 24,075 & 14,030 & 23,051 & 23,051 & 13,421 & 22,756 & 22,756 & 13,261 \\
\hline pseudo R-sq & 0.046 & 0.037 & 0.193 & 0.045 & 0.036 & 0.192 & 0.045 & 0.037 & 0.201 \\
\hline
\end{tabular}

Note: This table presents the estimation result of equation (6) using alternative proxies for accounting quality (discussed in Appendix 2). The dependent variable, $C L \_A c c t$ (CL_Core), is equal to one if the company received a 10-K comment letter in which accounting (core earnings) issues were discussed for the fiscal year $\mathrm{t}$ filing, and zero otherwise. $C L 3 Y r$ is equal to one if the firm received a comment letter on its $10-\mathrm{K}$ filing for fiscal year $\mathrm{t}$, and zero if the firm did not receive a 10 $\mathrm{K}$ comment letter for fiscal years t, t-1, and t-2. Z-statistics are in parentheses. Year dummies and AD Office dummies are included. Continuous variables are winsorized at the $1 \%$ and $99 \%$ levels. $* * *, * * *$ indicate significance at the $10 \%, 5 \%$ and $1 \%$ levels (two-tailed), respectively. Standard errors are clustered at the firm level. 
TABLE A2-2

Robustness of the Results to the Measurement of Accounting Quality (Replication of Table 5)

Panel A: Alternative Discretionary Accruals Models

\begin{tabular}{|c|c|c|c|c|c|c|c|c|c|c|}
\hline & & \multicolumn{3}{|c|}{ Jones Model } & \multicolumn{3}{|c|}{ Jones Model - ROA } & \multicolumn{3}{|c|}{ Modified Jones - ROA } \\
\hline & & $C L \_A c c t$ & CL_Core & $C L \_3 Y r$ & CL_Acct & CL_Core & $C L \_3 Y r$ & $C L \_A c c t$ & CL_Core & $C L \_3 Y r$ \\
\hline Logit & Pred. & $(1)$ & $(2)$ & (3) & (4) & $(5)$ & $(6)$ & $(7)$ & $(8)$ & (9) \\
\hline Poor Accounting Quality $x$ High Comp & + & $\begin{array}{c}0.775 * * \\
(2.06)\end{array}$ & $\begin{array}{c}0.979 * * \\
(2.21)\end{array}$ & $\begin{array}{c}1.783 * * * \\
(3.06)\end{array}$ & $\begin{array}{l}0.892^{*} \\
(1.67)\end{array}$ & $\begin{array}{c}1.727 * * * \\
(2.69)\end{array}$ & $\begin{array}{c}3.198 * * * \\
(4.08)\end{array}$ & $\begin{array}{l}0.849 \dagger \\
(1.58)\end{array}$ & $\begin{array}{c}1.747 * * * \\
(2.71)\end{array}$ & $\begin{array}{c}3.182 * * * \\
(4.06)\end{array}$ \\
\hline Poor Accounting Quality & & $\begin{array}{c}-0.251 * \\
(-1.90)\end{array}$ & $\begin{array}{l}-0.201 \\
(-1.36)\end{array}$ & $\begin{array}{l}-0.077 \\
(-0.54)\end{array}$ & $\begin{array}{l}-0.289 \\
(-1.09)\end{array}$ & $\begin{array}{l}-0.293 \\
(-0.97)\end{array}$ & $\begin{array}{c}-0.661 * * \\
(-2.05)\end{array}$ & $\begin{array}{l}-0.301 \\
(-1.14)\end{array}$ & $\begin{array}{l}-0.287 \\
(-0.95)\end{array}$ & $\begin{array}{c}-0.715^{* *} \\
(-2.20)\end{array}$ \\
\hline High Comp & & $\begin{array}{l}-0.016 \\
(-0.37)\end{array}$ & $\begin{array}{l}-0.050 \\
(-0.94)\end{array}$ & $\begin{array}{l}-0.071 \\
(-1.08)\end{array}$ & $\begin{array}{l}-0.018 \\
(-0.38)\end{array}$ & $\begin{array}{l}-0.085 \\
(-1.46)\end{array}$ & $\begin{array}{c}-0.140 * * \\
(-1.98)\end{array}$ & $\begin{array}{l}-0.015 \\
(-0.33)\end{array}$ & $\begin{array}{l}-0.086 \\
(-1.47)\end{array}$ & $\begin{array}{c}-0.139 * * \\
(-1.98)\end{array}$ \\
\hline Controls & & Yes & Yes & Yes & Yes & Yes & Yes & Yes & Yes & Yes \\
\hline $\begin{array}{l}\mathrm{N} \\
\text { pseudo R-sq }\end{array}$ & & $\begin{array}{c}24,075 \\
0.046\end{array}$ & $\begin{array}{c}24,075 \\
0.037\end{array}$ & $\begin{array}{c}14,030 \\
0.193\end{array}$ & $\begin{array}{c}24,075 \\
0.045\end{array}$ & $\begin{array}{c}24,075 \\
0.037\end{array}$ & $\begin{array}{c}14,030 \\
0.194\end{array}$ & $\begin{array}{c}24,075 \\
0.045\end{array}$ & $\begin{array}{c}24,075 \\
0.037\end{array}$ & $\begin{array}{c}14,030 \\
0.194\end{array}$ \\
\hline Mean Interaction Effect & + & $\begin{array}{c}0.147 * * \\
(2.04)\end{array}$ & $\begin{array}{c}0.128 * * \\
(2.15)\end{array}$ & $\begin{array}{c}0.332 * * * \\
(2.98)\end{array}$ & $\begin{array}{l}0.169 * \\
(1.65)\end{array}$ & $\begin{array}{c}0.227 * * * \\
(2.60)\end{array}$ & $\begin{array}{c}0.595 * * * \\
(3.91)\end{array}$ & $\begin{array}{l}0.161 \dagger \\
(1.57)\end{array}$ & $\begin{array}{c}0.229 * * * \\
(2.61)\end{array}$ & $\begin{array}{c}0.593 \text { *** } \\
(3.90)\end{array}$ \\
\hline
\end{tabular}

Panel B: Alternative Accounting Quality Proxies

\begin{tabular}{|c|c|c|c|c|c|c|c|c|c|c|}
\hline & & \multicolumn{3}{|c|}{$\operatorname{Std}(R O A)$} & \multicolumn{3}{|c|}{ Accruals Quality } & \multicolumn{3}{|c|}{ Unexpected Audit Fees } \\
\hline & & $C L \_A c c t$ & CL_Core & $C L \_3 Y r$ & $C L \_A c c t$ & CL_Core & $C L \_3 Y r$ & $C L \_A c c t$ & CL_Core & $C L \_3 Y r$ \\
\hline Logit & Pred. & $(1)$ & $(2)$ & (3) & $(4)$ & $(5)$ & $(6)$ & $(7)$ & $(8)$ & $(9)$ \\
\hline Poor Accounting Quality $x$ High Comp & + & $\begin{array}{c}2.488 * * \\
(2.04)\end{array}$ & $\begin{array}{c}3.311 * * \\
(2.31)\end{array}$ & $\begin{array}{c}7.355 * * * \\
(3.19)\end{array}$ & $\begin{array}{l}2.809 \dagger \\
(1.63)\end{array}$ & $\begin{array}{c}5.020 * * \\
(2.45)\end{array}$ & $\begin{array}{c}7.092 * * \\
(2.38)\end{array}$ & $\begin{array}{c}0.232 * * * \\
(3.45)\end{array}$ & $\begin{array}{c}0.184 * * \\
(2.34)\end{array}$ & $\begin{array}{c}0.268 * * \\
(2.40)\end{array}$ \\
\hline Poor Accounting Quality & & $\begin{array}{c}-1.618 * * * \\
(-3.22)\end{array}$ & $\begin{array}{c}-1.62 * * * \\
(-2.79)\end{array}$ & $\begin{array}{c}-1.725 * * \\
(-2.42)\end{array}$ & $\begin{array}{l}-0.389 \\
(-0.46)\end{array}$ & $\begin{array}{l}0.910 \\
(0.96)\end{array}$ & $\begin{array}{l}-0.885 \\
(-0.68)\end{array}$ & $\begin{array}{c}-0.091 * \\
(-1.92)\end{array}$ & $\begin{array}{l}-0.078 \\
(-1.38)\end{array}$ & $\begin{array}{l}-0.049 \\
(-0.64)\end{array}$ \\
\hline High Comp & & $\begin{array}{l}-0.036 \\
(-0.80)\end{array}$ & $\begin{array}{l}-0.073 \\
(-1.34)\end{array}$ & $\begin{array}{c}-0.120 * \\
(-1.67)\end{array}$ & $\begin{array}{l}-0.043 \\
(-0.76)\end{array}$ & $\begin{array}{l}-0.115 \\
(-1.63)\end{array}$ & $\begin{array}{c}-0.158 * \\
(-1.71)\end{array}$ & $\begin{array}{l}0.023 \\
(0.63)\end{array}$ & $\begin{array}{l}0.006 \\
(0.13)\end{array}$ & $\begin{array}{l}0.012 \\
(0.21)\end{array}$ \\
\hline Controls & & Yes & Yes & Yes & Yes & Yes & Yes & Yes & Yes & Yes \\
\hline $\begin{array}{l}\mathrm{N} \\
\text { pseudo R-sq }\end{array}$ & & $\begin{array}{c}24,075 \\
0.046\end{array}$ & $\begin{array}{c}24,075 \\
0.037\end{array}$ & $\begin{array}{c}14,030 \\
0.194\end{array}$ & $\begin{array}{c}23,051 \\
0.045\end{array}$ & $\begin{array}{c}23,051 \\
0.037\end{array}$ & $\begin{array}{c}13,421 \\
0.192\end{array}$ & $\begin{array}{c}22,756 \\
0.045\end{array}$ & $\begin{array}{c}22,756 \\
0.037\end{array}$ & $\begin{array}{c}13,261 \\
0.201\end{array}$ \\
\hline Mean Interaction Effect & + & $\begin{array}{c}0.468 * * \\
(1.98)\end{array}$ & $\begin{array}{c}0.434 * * \\
(2.21)\end{array}$ & $\begin{array}{c}1.361 * * * \\
(3.14)\end{array}$ & $\begin{array}{l}0.533 \dagger \\
(1.61)\end{array}$ & $\begin{array}{c}0.669 * * \\
(2.37)\end{array}$ & $\begin{array}{c}1.332 * * \\
(2.34)\end{array}$ & $\begin{array}{c}0.041 * * * \\
(3.08)\end{array}$ & $\begin{array}{c}0.023 * * \\
(2.21)\end{array}$ & $\begin{array}{c}0.048 * * \\
(2.28)\end{array}$ \\
\hline
\end{tabular}

Note: This table presents the estimation result of equation (7) using alternative proxies for accounting quality (discussed in Appendix 2). The dependent variable, CL_Acct (CL_Core), is equal to one if the company received a 10-K comment letter in which accounting (core earnings) issues were discussed for the fiscal year t filing, and zero otherwise. $C L \_3 Y r$ is equal to one if the firm received a comment letter on its $10-\mathrm{K}$ filing for fiscal year $\mathrm{t}$, and zero if the firm did not receive a 10 $\mathrm{K}$ comment letter for fiscal years t, t-1, and t-2. Z-statistics are in parentheses. Year dummies and AD Office dummies are included. Continuous variables are winsorized at the $1 \%$ and $99 \%$ levels. $* * *, * * *$ indicate significance at the $10 \%, 5 \%$ and $1 \%$ levels (two-tailed), respectively. Standard errors are clustered at the firm level. Following the procedure in Norton et al. (2004), the mean interaction effects are provided and the mean $\mathrm{z}$-statistics are in parentheses. 
TABLE A2-3

Robustness of the Results to the Measurement of Comparability

\begin{tabular}{|c|c|c|c|c|c|c|c|c|c|c|}
\hline & & \multicolumn{3}{|c|}{ High_Comp_DD } & \multicolumn{3}{|c|}{ High_Comp_PLE } & \multicolumn{3}{|c|}{ High_Comp_BASU } \\
\hline & & $C L \_A c c t$ & CL_Core & $C L \_3 Y r$ & $C L \_A c c t$ & CL_Core & $C L \_3 Y r$ & $C L \_A c c t$ & CL_Core & $C L \_3 Y r$ \\
\hline Logit & Pred. & $(1)$ & $(2)$ & (3) & $(4)$ & $(5)$ & $(6)$ & $(7)$ & $(8)$ & $(9)$ \\
\hline Disc_Accrx Alt_High Comp & + & $\begin{array}{l}0.520 \\
(1.26)\end{array}$ & $\begin{array}{c}1.050 * * \\
(2.18)\end{array}$ & $\begin{array}{c}2.211 * * * \\
(3.71)\end{array}$ & $\begin{array}{c}0.888 * * \\
(2.17)\end{array}$ & $\begin{array}{c}1.187 * * \\
(2.45)\end{array}$ & $\begin{array}{c}1.860 * * * \\
(2.97)\end{array}$ & $\begin{array}{c}1.085 * * \\
(2.37)\end{array}$ & $\begin{array}{c}1.256^{* *} \\
(2.36)\end{array}$ & $\begin{array}{c}2.028 * * * \\
(2.85)\end{array}$ \\
\hline Disc_Accr & & $\begin{array}{l}-0.285 \\
(-1.24)\end{array}$ & $\begin{array}{l}-0.301 \\
(-1.18)\end{array}$ & $\begin{array}{c}-0.600 * * \\
(-2.14)\end{array}$ & $\begin{array}{l}-0.272 \\
(-1.20)\end{array}$ & $\begin{array}{l}-0.220 \\
(-0.88)\end{array}$ & $\begin{array}{l}-0.419 \\
(-1.58)\end{array}$ & $\begin{array}{l}-0.277 \\
(-1.23)\end{array}$ & $\begin{array}{l}-0.167 \\
(-0.68)\end{array}$ & $\begin{array}{l}-0.427 \\
(-1.63)\end{array}$ \\
\hline Alt_High Comp & & $\begin{array}{l}-0.041 \\
(-0.92)\end{array}$ & $\begin{array}{l}-0.077 \\
(-1.46)\end{array}$ & $\begin{array}{l}-0.067 \\
(-1.01)\end{array}$ & $\begin{array}{l}-0.018 \\
(-0.41)\end{array}$ & $\begin{array}{l}-0.078 \\
(-1.42)\end{array}$ & $\begin{array}{l}-0.105 \\
(-1.54)\end{array}$ & $\begin{array}{l}0.001 \\
(0.01)\end{array}$ & $\begin{array}{l}0.026 \\
(0.47)\end{array}$ & $\begin{array}{l}-0.142 * \\
(-1.95)\end{array}$ \\
\hline Controls & & Yes & Yes & Yes & Yes & Yes & Yes & Yes & Yes & Yes \\
\hline $\begin{array}{l}\mathrm{N} \\
\text { pseudo R-sq }\end{array}$ & & $\begin{array}{c}22,758 \\
0.046\end{array}$ & $\begin{array}{c}22,758 \\
0.038\end{array}$ & $\begin{array}{c}13,339 \\
0.194\end{array}$ & $\begin{array}{c}24,075 \\
0.046\end{array}$ & $\begin{array}{c}24,075 \\
0.037\end{array}$ & $\begin{array}{c}14,030 \\
0.193\end{array}$ & $\begin{array}{c}23,908 \\
0.046\end{array}$ & $\begin{array}{c}23,908 \\
0.037\end{array}$ & $\begin{array}{c}13,937 \\
0.193\end{array}$ \\
\hline Mean Interaction Effect & + & $\begin{array}{l}0.098 \\
(1.25)\end{array}$ & $\begin{array}{c}0.137 * * \\
(2.12)\end{array}$ & $\begin{array}{c}0.413 * * * \\
(3.56)\end{array}$ & $\begin{array}{c}0.168 * * \\
(2.14)\end{array}$ & $\begin{array}{c}0.155^{* *} \\
(2.38)\end{array}$ & $\begin{array}{c}0.347 * * * \\
(2.89)\end{array}$ & $\begin{array}{c}0.207 * * \\
(2.33)\end{array}$ & $\begin{array}{c}0.169 * * \\
(2.30)\end{array}$ & $\begin{array}{c}0.377 * * * \\
(2.79)\end{array}$ \\
\hline
\end{tabular}

(continued)

\begin{tabular}{|c|c|c|c|c|c|c|c|}
\hline & & \multicolumn{3}{|c|}{ High_Comp_BLLWI } & \multicolumn{3}{|c|}{ High_Comp_BLLW2 } \\
\hline & & $C L \_A c c t$ & CL_Core & $C L \_3 Y r$ & $C L \_A c c t$ & CL_Core & $C L \_3 Y r$ \\
\hline Logit & Pred. & $(10)$ & $(11)$ & $(12)$ & (13) & $(14)$ & $(15)$ \\
\hline Disc_Accr x Alt_High Comp & + & $\begin{array}{l}0.751^{*} \\
(1.89)\end{array}$ & $\begin{array}{c}1.184 * * \\
(2.54)\end{array}$ & $\begin{array}{c}1.409 * * \\
(2.48)\end{array}$ & $\begin{array}{l}-0.157 \\
(-0.31)\end{array}$ & $\begin{array}{l}0.160 \\
(0.30)\end{array}$ & $\begin{array}{l}0.096 \\
(0.09)\end{array}$ \\
\hline Disc_Accr & & $\begin{array}{l}-0.301 \\
(-1.31)\end{array}$ & $\begin{array}{l}-0.297 \\
(-1.16)\end{array}$ & $\begin{array}{c}-0.476^{*} \\
(-1.79)\end{array}$ & $\begin{array}{l}0.090 \\
(0.27)\end{array}$ & $\begin{array}{l}0.181 \\
(0.38)\end{array}$ & $\begin{array}{l}0.311 \\
(0.47)\end{array}$ \\
\hline Alt_High Comp & & $\begin{array}{c}-0.103 * * \\
(-2.32)\end{array}$ & $\begin{array}{c}-0.153 * * * \\
(-2.85)\end{array}$ & $\begin{array}{c}-0.188 * * * \\
(-2.85)\end{array}$ & $\begin{array}{l}0.060 \\
(0.91)\end{array}$ & $\begin{array}{l}-0.023 \\
(-0.28)\end{array}$ & $\begin{array}{l}0.064 \\
(0.72)\end{array}$ \\
\hline Controls & & Yes & Yes & Yes & Yes & Yes & Yes \\
\hline $\begin{array}{l}\mathrm{N} \\
\text { pseudo R-sq }\end{array}$ & & $\begin{array}{c}23,906 \\
0.046\end{array}$ & $\begin{array}{c}23,906 \\
0.037\end{array}$ & $\begin{array}{c}13,936 \\
0.193\end{array}$ & $\begin{array}{c}14,835 \\
0.035\end{array}$ & $\begin{array}{c}14,835 \\
0.034\end{array}$ & $\begin{array}{l}8,601 \\
0.150\end{array}$ \\
\hline Mean Interaction Effect & + & $\begin{array}{c}0.141^{*} \\
(1.88)\end{array}$ & $\begin{array}{c}0.153 * * \\
(2.45)\end{array}$ & $\begin{array}{c}0.261 * * \\
(2.43)\end{array}$ & $\begin{array}{l}-0.032 \\
(-0.27)\end{array}$ & $\begin{array}{l}-0.021 \\
(-0.24)\end{array}$ & $\begin{array}{l}-0.016 \\
(-0.10)\end{array}$ \\
\hline
\end{tabular}

Note: This table presents the estimation result of equation (7) using alternative financial statement comparability measures (discussed in Appendix 2). The dependent variable, $C L \_A c c t$ (CL_Core), is equal to one if the company received a 10-K comment letter in which accounting (core earnings) issues were discussed for the fiscal year t filing, and zero otherwise. $C L 3 \mathrm{Yr}$ is equal to one if the firm received a comment letter on its $10-\mathrm{K}$ filing for fiscal year t, and zero if the firm did not receive a 10-K comment letter for fiscal years $\mathrm{t}, \mathrm{t}-1$, and $\mathrm{t}-2$. Z-statistics are in parentheses. Year dummies and AD Office dummies are included. Continuous variables are winsorized at the $1 \%$ and $99 \%$ levels. *, **, *** indicate significance at the $10 \%, 5 \%$ and $1 \%$ levels (two-tailed), respectively. Standard errors are clustered at the firm level. Following the procedure in Norton et al. (2004), the mean interaction effects are provided and the mean z-statistics are in parentheses. 